Check for updates

Cite this: RSC Adv., 2018, 8, 18204

\title{
New bioactive cyclopeptide alkaloids with rare terminal unit from the root bark of Ziziphus cambodiana $\uparrow$
}

\author{
Natthakaln Lomchoey, (D) a Panomwan Panseeta, (D) ab Pornthip Boonsri, ${ }^{a}$ \\ Nuttapon Apiratikul, ${ }^{a}$ Samran Prabpai, ${ }^{c}$ Palangpon Kongsaeree (iD) ${ }^{c}$ \\ and Sunit Suksamrarn (DD*a
}

Six new 14-membered ring cyclopeptide alkaloids, cambodines A-F (1-6), and two known compounds, frangufoline (7) and lotusanine B (8), were isolated from the root bark extract of Ziziphus cambodiana Pierre. Their structures and configurations were established based on 1D and 2D NMR, HRMS, ECD, and X-ray crystallographic data. Compounds 1 and 3 are rare 5(14)-type cyclopeptide alkaloids that possess an imidazolidin-4-one ring in the terminal unit. The cyclopeptides were tested for their in vitro antiplasmodial, antitubercular, and cytotoxic effects against three cancer cell lines. Compound 3 showed significant antiplasmodial activity against the malarial parasite Plasmodium falciparum, with an $I_{50}$ value of $6.09 \mu \mathrm{M}$.

Received 5th December 2017

Accepted 2nd May 2018

DOI: $10.1039 / \mathrm{c} 7 \mathrm{ra13050c}$

rsc.li/rsc-advances

with two known compounds, $7^{\mathbf{1 9}}$ and $\mathbf{8},{ }^{\mathbf{2 0}}$ from the root bark of Z. cambodiana are reported. Compounds $\mathbf{1}$ and $\mathbf{3}$ are additional representatives of the (5)14-membered ring cyclopeptide series, with a terminal imidazolidinone ring. Interestingly, these 8 cyclopeptides pose a challenging problem in the determination of the absolute configuration. Electronic circular dichroism (ECD) have been widely used in the determination the absolute configuration, and a great number of chiral compounds have been well investigated via theoretical methods. ${ }^{21-26}$ Among the techniques employed to compute electronic transitions, TDDFT is the most widely used and most efficient method for the study of excited states and the prediction of ECD spectra. It has been successfully applied for the description of the conformational structures and the electronic spectra of natural products, metal complexes and other organic molecules. ${ }^{27-31} \mathrm{In}$ the present work, the DFT and TD-DFT methods were applied to simulate the ECD spectra in order to confirm the structure assignment obtained from NMR spectroscopy and the observed ECD spectra. Finally, the in vitro antimalarial, antimycobacterial, and cytotoxic activities of the isolated compounds are also described.

\section{Results and discussion}

${ }^{a}$ Department of Chemistry and Center of Excellence for Innovation in Chemistry Faculty of Science, Srinakharinwirot University, Bangkok 10110, Thailand. E-mail: sunit@g.swu.ac.th

${ }^{b}$ Department of Chemistry, Chulachomklao Royal Military Academy, Nakornnayok 26001, Thailand

'Department of Chemistry and Center for Excellence in Protein Structure and Function, Faculty of Science, Mahidol University, Bangkok 10400, Thailand

$\dagger$ Electronic supplementary information (ESI) available. CCDC 1469415. For ESI and crystallographic data in CIF or other electronic format see DOI: $10.1039 / \mathrm{c} 7 \mathrm{ra} 13050 \mathrm{c}$

Chemical investigations of the EtOAc and $\mathrm{MeOH}$ extracts of $Z$. cambodiana root bark resulted in the isolation of three 14membered ring cyclopeptide alkaloids, cambodines A (1), B (4), and $\mathrm{C}(2)$, and known compounds 7 and 8. The removal of tannins from the $\mathrm{MeOH}$ extract with $\mathrm{NaCl}$ solution $(1 \% \mathrm{v} / \mathrm{v})$ followed by partitioning with EtOAc yielded a detannified EtOAc-soluble fraction that was column chromatographed to 
furnish three additional cyclopeptides: cambodines D (5), E (6), and F (3) (Fig. 1).

Several common chemical and spectroscopic characteristics were evident for compounds 1-8. They displayed a blue colour upon staining with anisaldehyde- $\mathrm{H}_{2} \mathrm{SO}_{4}$ reagent on TLC. ${ }^{13}$ Their IR spectra showed absorption bands for amide (3266-3338 and $\left.1632-1685 \mathrm{~cm}^{-1}\right)$ and aryl ether (1221-1237 $\mathrm{cm}^{-1}$ ) functionalities. The ECD spectra of compounds 1-8 showed intense negative and weak positive Cotton effects in the 236-244 and 279-286 nm regions, respectively, consistent with the $(5 S, 8 S, 9 S)$-configurations. ${ }^{32}$ Their ${ }^{1} \mathrm{H}$ and ${ }^{13} \mathrm{C}$ NMR data agreed well with the published values for 5(14)-scutianine A-type (1-3), 4(14)-integerrine-type (4-6), 4(14)-frangulanine-type (7), and 5(14)-neutral-type cyclopeptide alkaloid (8).

Compound 1 was isolated as a colourless amorphous solid. The HRESITOFMS data showed a protonated ion at $\mathrm{m} / \mathrm{z}$ $680.3808[\mathrm{M}+\mathrm{H}]^{+}$, in accordance with a molecular formula $\mathrm{C}_{40} \mathrm{H}_{49} \mathrm{~N}_{5} \mathrm{O}_{5}$. The ${ }^{13} \mathrm{C}$ NMR and DEPT data in DMSO- $d_{6}$ (Table 1) revealed 40 carbon resonances, which were classified as four methyls $\left(\delta_{\mathrm{C}} 10.8,12.0,14.5,15.4\right)$, an $N$-methyl $\left(\delta_{\mathrm{C}} 40.5\right)$, four methylenes $\left(\delta_{\mathrm{C}} 24.0,24.3,34.2,66.3\right), 23$ methines (six aliphatic at $\delta_{\mathrm{C}} 35.0,35.5,53.4,56.0,57.4,69.7$, one oxygenated at $\delta_{\mathrm{C}} 80.8$, two olefinic at $\delta_{\mathrm{C}} 125.8$ and 126.7 and 14 aromatic at $\delta_{\mathrm{C}} 119.5$, $121.8,126.2,127.6 \times 2,127.9 \times 3,128.4 \times 2,128.8 \times 2,129.5$, $130.0)$, four amide carbonyls $\left(\delta_{\mathrm{C}} 167.4,168.9,169.9,170.7\right)$, three aromatic quaternary $\left(\delta_{\mathrm{C}} 131.5,136.7\right.$, and 137.8), and an oxygenated tertiary $\left(\delta_{\mathrm{C}}\right.$ 154.7). Interpretation of the ${ }^{1} \mathrm{H},{ }^{13} \mathrm{C}$ NMR, and 2D NMR spectroscopic data and the IR absorption frequencies at $3289,1682,1636$, and $1241 \mathrm{~cm}^{-1}$ led to the conclusion that 1 was a 5(14)-type cyclopeptide alkaloid in which the cyclic part comprised a phenylalanine, an $p$-oxystyrylamine with a $Z$ double bond, an isoleucine moiety, in addition to the coupled phenylalanine and $\mathrm{N}$-methylisoleucine moiety as the terminal unit (Fig. 1). The assembly of these fragments was made possible on the basis of correlations in the COSY, HMBC, and NOESY experiments (Fig. 2). The HMBC spectrum showed correlations of the olefinic $\mathrm{H}-2\left(\delta_{\mathrm{H}} 6.23, \mathrm{dd}, J\right.$ $=7.3,4.5 \mathrm{~Hz})$ to the $\mathrm{C}-4$ carbonyl carbon resonance $\left(\delta_{\mathrm{C}} 168.9\right)$ and of the oxygenated methine $\mathrm{H}-9\left(\delta_{\mathrm{H}} 5.84, \mathrm{~d}, J=8.1 \mathrm{~Hz}\right)$ and isoleucyl H-5 $\left(\delta_{\mathrm{H}} 3.81, \mathrm{t}, J=8.5 \mathrm{~Hz}\right)$ to $\mathrm{C}-7\left(\delta_{\mathrm{C}} 169.9\right)$, in addition to the NOESY cross-peaks between $\mathrm{H}-9$ and the aromatic resonances $\mathrm{H}-12\left(\delta_{\mathrm{H}} 7.14\right)$ and $\mathrm{H}-22\left(\delta_{\mathrm{H}} 7.44\right.$, dd, $\left.J=7.7,2.2 \mathrm{~Hz}\right)$ established the linkage of the $p$-oxystyrylamine moiety to the phenylalanine unit and the location of this dimeric moiety in the macrocyclic ring. The $\mathrm{H}-8$ methine signal at $\delta_{\mathrm{H}} 4.78$ (brt, $J=$ $8.8 \mathrm{~Hz}$ ) showed an HMBC cross-peak to the phenylalanine carbonyl C-26 $\left(\delta_{\mathrm{C}} 167.4\right)$, indicating the connection between the phenylalanine units. A prominent fragment ion at $\mathrm{m} / \mathrm{z} 622$ and a base peak at $m / z 155$ in the EIMS spectrum of $\mathbf{1}$ (the molecular ion of which is presented as $\mathbf{1}^{\prime}$ in Fig. 3) indicated the fragmentations of the corresponding $N$-methylimidazolidin-4-one to produce $\mathbf{1}^{\prime} \mathbf{a}$ and the terminal residue $\mathbf{1}^{\prime} \mathbf{b},{ }^{33,34}$ respectively (Fig. 3). The relatively low field chemical shifts of the two diastereotopic protons at $\delta_{\mathrm{H}} 3.99$ and 3.11 (each $\mathrm{d}, J=4.4 \mathrm{~Hz}, \mathrm{H}$ 41a and $\mathrm{H}-41 \mathrm{~b}$, respectively), $\delta_{\mathrm{C}} 66.3$ (C-41), an $N$-methyl $\left(\delta_{\mathrm{H}}\right.$ $2.13)$, a sec-butyl group $\left(\delta_{\mathrm{H}} 1.23, \mathrm{~m}, \mathrm{H}-36, \delta_{\mathrm{C}} 35.0 ; \delta_{\mathrm{H}} 0.99, \mathrm{~m}, \mathrm{H}-\right.$

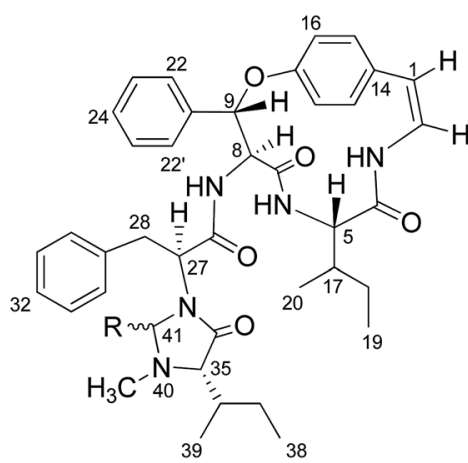

Cambodine A (1): $\mathrm{R}=\mathrm{H}$ Cambodine $\mathrm{F}(3): \mathrm{R}=\mathrm{CH}_{3}$

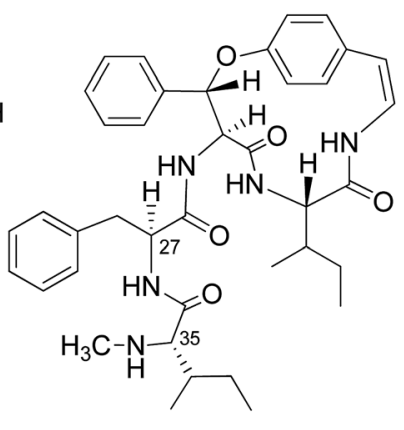

Cambodine C (2)

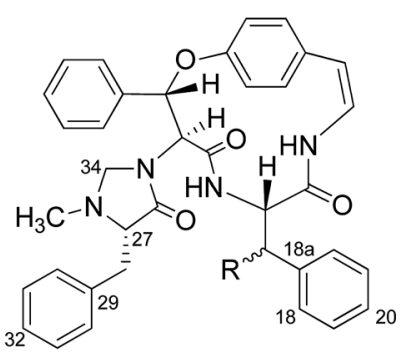

Cambodine $\mathrm{B}(4): \mathrm{R}=\mathrm{OH}$ Cambodine $E(6): R=H$

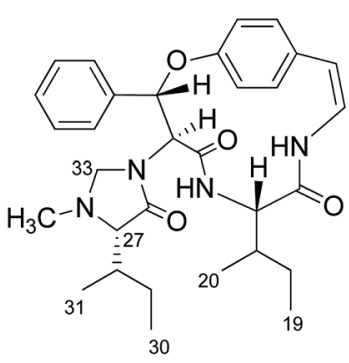

Cambodine D (5)

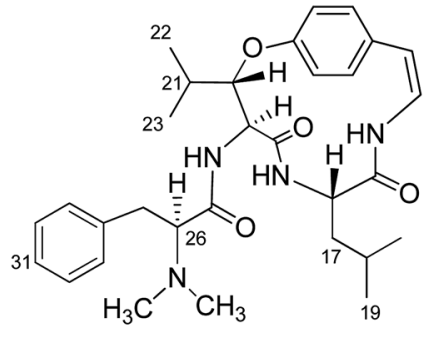

Frangufoline (7)

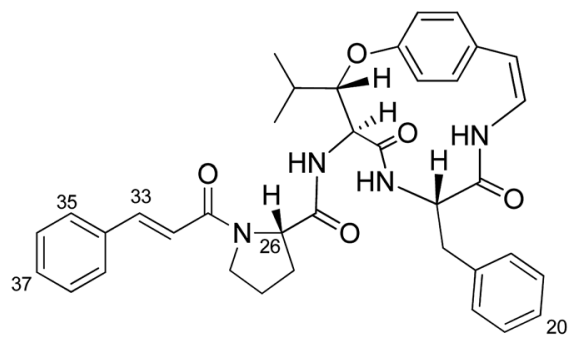

Lotusanine B (8)

Fig. 1 Chemical structures of compounds 1-8. 
Table $1{ }^{1} \mathrm{H}$ and ${ }^{13} \mathrm{C}$ NMR spectroscopic data for compounds $1-3$

\begin{tabular}{|c|c|c|c|c|c|c|c|c|}
\hline \multirow[b]{2}{*}{ No. } & \multicolumn{4}{|l|}{$\delta_{\mathrm{C}}$} & \multicolumn{4}{|l|}{$\delta_{\mathrm{H}}$} \\
\hline & $\mathbf{1}^{a}$ & $2^{a}$ & $2^{b}$ & $3^{b}$ & $\mathbf{1}^{a}$ & $2^{a}$ & $2^{b}$ & $3^{b}$ \\
\hline 1 & 125.8 & 127.5 & 117.5 & 117.5 & $6.60, \mathrm{~d}(7.3)$ & $6.63, \mathrm{~d}(7.3)$ & $6.44, \mathrm{~d}(7.1)$ & $6.45, \mathrm{~d}(7.4)$ \\
\hline 2 & 126.7 & 126.7 & 125.5 & 125.4 & 6.23, dd $(7.3,4.5)$ & 6.14, dd $(7.3,3.4)$ & 6.65, dd $(9.6,7.1)$ & 6.65, dd $(9.2,7.4)$ \\
\hline 4 & 168.9 & 169.0 & 167.2 & 167.2 & & & & \\
\hline 5 & 57.4 & 57.3 & 59.3 & 59.3 & $3.81, \mathrm{t}(8.5)$ & $3.81, \mathrm{t}(8.9)$ & $4.08, \mathrm{dd}(8.3,4.1)$ & 3.98, dd $(8.0,3.9)$ \\
\hline 7 & 169.9 & 170.2 & 171.0 & 171.0 & & & & \\
\hline 8 & 56.0 & 55.9 & 56.7 & 57.2 & 4.78, brt $(8.8)$ & $4.83, \mathrm{dt}(9.8,7.9)$ & $4.78, \mathrm{dd}(8.9,6.7)$ & 4.70, dd $(8.4,7.1)$ \\
\hline 9 & 80.8 & 80.9 & 81.5 & 81.6 & $5.84, \mathrm{~d}(8.1)$ & $5.84, \mathrm{~d}(7.9)$ & $6.10, \mathrm{~d}(6.7)$ & $6.17, \mathrm{~d}(7.1)$ \\
\hline 11 & 154.7 & 154.8 & 155.1 & 155.2 & & & & \\
\hline 12 & 121.8 & 118.1 & 123.1 & 122.9 & 7.14, overlap & 7.16, overlap & 7.32, overlap & 7.35, dd $(8.4,2.1)$ \\
\hline 13 & 129.5 & 129.4 & 130.1 & 130.1 & $6.96, \mathrm{~d}(6.9)$ & 6.96 , overlap & 7.15 , overlap & 7.17 , overlap \\
\hline 14 & 131.5 & 131.2 & 132.5 & 132.2 & & & & \\
\hline 15 & 130.0 & 129.9 & 131.9 & 131.8 & $6.93, \mathrm{~d}(6.9)$ & 6.95 , overlap & 7.11, overlap & 7.12, overlap \\
\hline 16 & 119.5 & 121.1 & 122.6 & 122.5 & 7.19, overlap & 7.06 , overlap & 7.34 , overlap & 7.40, dd $(8.4,2.1)$ \\
\hline 17 & 35.5 & 37.2 & 35.2 & 35.3 & $1.58, \mathrm{~m}$ & $1.45, \mathrm{~m}$ & $2.11, \mathrm{~m}$ & $2.04, \mathrm{~m}$ \\
\hline 18 & 24.0 & 24.5 & 23.9 & 23.9 & $\begin{array}{l}\text { a } 1.16, \mathrm{~m} \\
\text { b } 0.99, \mathrm{~m}\end{array}$ & $\begin{array}{l}\text { a } 1.15, \mathrm{~m} \\
\text { b } 0.80, \mathrm{~m}\end{array}$ & $\begin{array}{l}\text { a } 1.25, \mathrm{~m} \\
\text { b } 0.80, \mathrm{~m}\end{array}$ & $\begin{array}{l}\text { a } 1.15, \mathrm{~m} \\
\text { b } 0.85, \mathrm{~m}\end{array}$ \\
\hline 19 & 10.8 & 11.3 & 11.9 & 11.9 & $0.66, \mathrm{t}(7.1)$ & 0.64 , overlap & $0.84, \mathrm{t}(7.2)$ & $0.79, \mathrm{t}(7.2)$ \\
\hline 20 & 15.4 & 15.2 & 15.8 & 16.4 & $0.65, \mathrm{t}(7.3)$ & 0.64 , overlap & $0.75, \mathrm{~d}(6.8)$ & $0.67, \mathrm{~d}(6.9)$ \\
\hline 21 & 137.8 & 137.5 & 136.8 & 137.2 & & & & \\
\hline $22,22^{\prime}$ & 128.4 & 128.6 & 128.1 & 128.2 & 7.44, dd $(7.7,2.2)$ & $7.49, \mathrm{~d}(6.9)$ & $7.51, \mathrm{dd}(7.5,1.0)$ & 7.67, brd $(7.2)$ \\
\hline $23,23^{\prime}$ & 127.6 & 127.7 & 128.8 & 128.8 & 7.28, overlap & $7.27, \mathrm{t}(6.9)$ & 7.40 , overlap & 7.48, brt $(7.4)$ \\
\hline 24 & 127.9 & 127.8 & 128.9 & 128.9 & 7.26 , overlap & 7.22 , overlap & 7.45 , overlap & 7.31, overlap \\
\hline 26 & 167.4 & 169.5 & 170.9 & 170.0 & & & & \\
\hline 27 & 53.4 & 53.0 & 54.7 & 63.0 & 4.58, dd $(10.7,5.1)$ & $4.23, \mathrm{dt}(10.8,7.9)$ & 4.20, dd $(10.4,4.8)$ & 3.49, dd $(11.9,4.4)$ \\
\hline 28 & 34.2 & 37.5 & 36.6 & 33.2 & $2.61, \mathrm{~m}$ & $\begin{array}{l}\text { a } 2.33, \text { dd }(11.2,7.9) \\
\text { b } 2.13, \text { brt }(11.2)\end{array}$ & $\begin{array}{l}\text { a } 2.88, \text { dd }(14.2,4.8) \\
\text { b } 2.45, \text { dd }(14.2,10.4)\end{array}$ & $\begin{array}{l}\text { a } 2.29, \text { brt }(12.6) \\
\text { b } 2.19, \text { dd }(12.6,4.4)\end{array}$ \\
\hline 29 & 136.7 & 137.7 & 136.3 & 136.6 & & & & \\
\hline $30,30^{\prime}$ & 128.8 & 129.0 & 128.9 & 129.2 & 7.02, overlap & 6.99 , overlap & $6.98, \mathrm{dd}(8.4,2.1)$ & 6.93, dd $(7.6,1.1)$ \\
\hline $31,31^{\prime}$ & 127.9 & 127.5 & 128.6 & 128.5 & 7.08 , overlap & 7.10 , overlap & 7.18 , overlap & 7.22 , overlap \\
\hline 32 & 126.2 & 126.0 & 127.0 & 127.0 & 7.07, overlap & 7.08 , overlap & 7.22 , overlap & 7.24 , overlap \\
\hline 34 & 170.7 & 172.2 & 174.2 & 174.8 & & & & \\
\hline 35 & 69.7 & 69.1 & 69.1 & 71.0 & 2.45, brs & 2.35, brs & $2.50, \mathrm{brs}$ & $2.57, \mathrm{brs}$ \\
\hline 36 & 35.0 & 36.1 & 37.6 & 36.5 & $1.23, \mathrm{~m}$ & $1.52, \mathrm{~m}$ & $1.51, \mathrm{~m}$ & $1.50, \mathrm{~m}$ \\
\hline 37 & 24.3 & 24.1 & 24.2 & 24.8 & $0.99, \mathrm{~m}$ & $\begin{array}{l}\text { a } 1.15, \mathrm{~m} \\
\text { b } 0.82, \mathrm{~m}\end{array}$ & $\begin{array}{l}\text { a } 0.86, \mathrm{~m} \\
\text { b } 0.70, \mathrm{~m}\end{array}$ & $1.28, \mathrm{~m}$ \\
\hline 38 & 12.0 & 10.9 & 11.7 & 12.2 & $0.67, \mathrm{t}(6.3)$ & 0.64 , overlap & $0.65, \mathrm{t}(6.0)$ & $0.85, \mathrm{t}(7.3)$ \\
\hline 39 & 14.5 & 15.4 & 15.5 & 14.9 & $0.41, \mathrm{~d}(6.8)$ & $0.46, \mathrm{~d}(6.7)$ & $0.62, \mathrm{~d}(6.9)$ & $0.77, \mathrm{~d}(6.8)$ \\
\hline 41 & 66.3 & & & 78.9 & $\begin{array}{l}\text { a } 3.99, \mathrm{~d}(4.4) \\
\text { b } 3.11, \mathrm{~d}(4.4)\end{array}$ & & & $2.41, \mathrm{q}(5.4)$ \\
\hline 42 & & & & 19.5 & & & & $0.92, \mathrm{~d}(5.4)$ \\
\hline $3-\mathrm{NH}$ & & & & & 7.84, brd $(4.5)$ & 8.05, brd $(3.4)$ & $6.73, \mathrm{~d}(9.6)$ & $6.52, \mathrm{~d}(9.2)$ \\
\hline $6-\mathrm{NH}$ & & & & & 7.54, brd $(8.5)$ & $7.62, \mathrm{~d}(8.9)$ & $6.19, \mathrm{~d}(8.3)$ & $5.92, \mathrm{~d}(8.0)$ \\
\hline $25-\mathrm{NH}$ & & & & & $8.23, \mathrm{~d}(9.4)$ & $7.93, \mathrm{~d}(8.9)$ & $6.84, \mathrm{~d}(8.9)$ & $8.73, \mathrm{~d}(8.4)$ \\
\hline 33-NH & & & & & & $7.64, \mathrm{~d}(7.9)$ & & \\
\hline $\mathrm{NMe}$ & 40.5 & 34.9 & 36.5 & 39.6 & $2.13, \mathrm{~s}$ & $1.79, \mathrm{~s}$ & $2.11, \mathrm{~s}$ & $1.85, \mathrm{~s}$ \\
\hline
\end{tabular}

$37, \delta_{\mathrm{C}} 24.3 ; \delta_{\mathrm{H}} 0.67, \mathrm{t}, J=6.3 \mathrm{~Hz}, \mathrm{H}-38, \delta_{\mathrm{C}} 12.0$; and $\delta_{\mathrm{H}} 0.41, \mathrm{~d}, J$ $\left.=6.8 \mathrm{~Hz}, \mathrm{H}-39, \delta_{\mathrm{C}} 14.5\right)$, and an amide carbonyl carbon at $\delta_{\mathrm{C}}$ 170.7 (C-34) further supported the presence of a 3-substituted 5(sec-butyl)-1-methylimidazolidin-4-one ring. Furthermore, the correlations of $\mathrm{H}-8, \mathrm{NH}-25\left(\delta_{\mathrm{H}} 8.23, \mathrm{~d}, J=9.4 \mathrm{~Hz}\right)$, and $\mathrm{H}-27\left(\delta_{\mathrm{H}}\right.$ 4.58, dd, $J=10.7$ and $5.1 \mathrm{~Hz})$ to $\mathrm{CO}-26\left(\delta_{\mathrm{C}} 167.4\right)$ in the HMBC spectrum along with the interactions of $\mathrm{H}-27$ to $\mathrm{H}-30\left(\delta_{\mathrm{H}} 7.02\right)$, of $\mathrm{H}-41$ a to $\mathrm{H}-28\left(\delta_{\mathrm{H}} 2.61 \mathrm{~m}\right)$ and $\mathrm{H}-30$, and of $\mathrm{N}-\mathrm{CH}_{3}$ to $\mathrm{H}-41 \mathrm{~b}$ in the NOESY experiments permitted the assignment of the linkage between both phenylalanine units to the imidazolidinone group. The HMBC cross-peaks of $\mathrm{H}-41 \mathrm{a}$ to CO-34, C-35 $\left(\delta_{\mathrm{C}}\right.$
69.7), and $\mathrm{N}-\mathrm{CH}_{3}$ and of $\mathrm{H}-35$ to $\mathrm{CO}-34$ and $\mathrm{C}-36\left(\delta_{\mathrm{C}} 35.0\right)$ and the NOESY interaction between $\mathrm{H}-35$ and $\mathrm{N}-\mathrm{CH}_{3}$ were also observed. Thus, the structure of cyclopeptide $\mathbf{1}$, cambodine A, was deduced as a new member of the 5(14)-scutianine A-type cyclopeptides.

Compound 2 was also obtained as a colourless amorphous solid. Its molecular formula was determined by the HRESITOFMS ion at $m / z 668.3807[\mathrm{M}+\mathrm{H}]^{+}$and ${ }^{13} \mathrm{C}$ NMR spectroscopic data as $\mathrm{C}_{39} \mathrm{H}_{49} \mathrm{~N}_{5} \mathrm{O}_{5}$. Its ${ }^{1} \mathrm{H}$ and ${ }^{13} \mathrm{C}$ NMR data in DMSO- $d_{6}$ (Table 1) were similar to those of $\mathbf{1}$, except for the absence of the two geminal protons at $\mathrm{C}-\mathbf{4 1}$ in $\mathbf{1}$ and the presence of an amide 

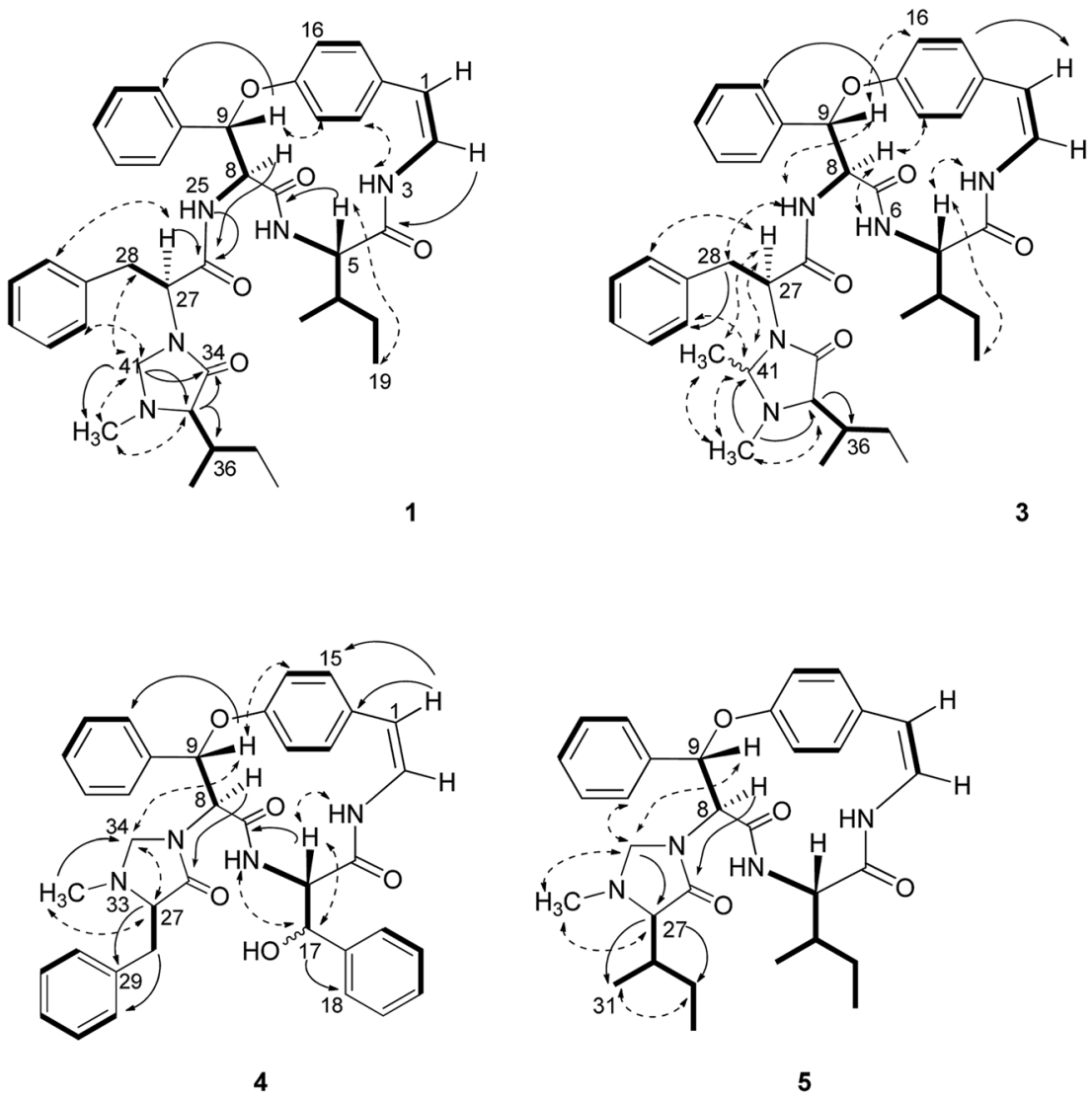

COSY NOESY

Fig. 2 Selected COSY, HMBC and NOESY interactions for compounds 1, 3, 4 and 5.

proton $\mathrm{NH}-33$ at $\delta_{\mathrm{H}} 7.64(1 \mathrm{H}, \mathrm{d}, J=7.9 \mathrm{~Hz})$ in 2 , which are in agreement with the structural change in the terminal residue (Fig. 1). The NMR data of 2 recorded in $\mathrm{CDCl}_{3}$ (Table 1) were similar to those observed in DMSO- $d_{6}$, except for the C-1 chemical shift. Information from the HMBC association of $\mathrm{H}$ -
$8\left(\delta_{\mathrm{H}} 4.83, \mathrm{dt}, J=9.8,7.9 \mathrm{~Hz}\right)$ to $\mathrm{CO}-26\left(\delta_{\mathrm{C}} 169.5\right)$ and of $\mathrm{NH}-$ 33 to CO-34 $\left(\delta_{\mathrm{C}} 172.2\right)$ in addition to the NOESY interactions of $\mathrm{H}-27\left(\delta_{\mathrm{H}} 4.23, \mathrm{dt}, J=10.8,7.9 \mathrm{~Hz}\right)$ to $\mathrm{NH}-25\left(\delta_{\mathrm{H}} 7.93, \mathrm{~d}, J=8.9\right.$ $\mathrm{Hz})$ and $\mathrm{H}-30\left(\delta_{\mathrm{H}} 6.99\right)$ and of $\mathrm{H}-35\left(\delta_{\mathrm{H}} 2.35\right.$, brs $)$ to $\mathrm{NCH}_{3}\left(\delta_{\mathrm{H}}\right.$ 1.79 , s) (Fig. 2) provided evidence for the exocyclic

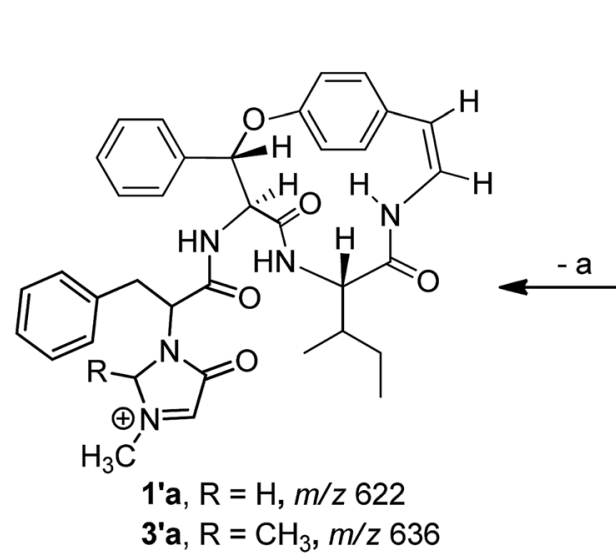

3'a, $\mathrm{R}=\mathrm{CH}_{3}, \mathrm{~m} / \mathrm{z} 636$<smiles>[R]C1N(C)C(=O)C(C(C)CC)N1C</smiles>

1 'b, $\mathrm{R}=\mathrm{H}, \mathrm{m} / \mathrm{z} 155$

3'b, $\mathrm{R}=\mathrm{CH}_{3}, \mathrm{~m} / \mathrm{z} 169$

$1 ', \mathrm{R}=\mathrm{H}, \mathrm{m} / \mathrm{z} 679$

3', $\mathrm{R}=\mathrm{CH}_{3}, \mathrm{~m} / \mathrm{z} 693$

Fig. $3 \mathrm{El}$ fragmentations of compounds 1 and 3 . 
phenylalanine moiety connecting to the macrocyclic ring at $\mathrm{N}$ 25 and the terminal $N$-methylisoleucine unit. The structure of 2, cambodine $\mathrm{C}$, was therefore also defined as a new 5(14)scutianine A-type compound.

Compound 3 displayed a sodium adduct molecular ion at $\mathrm{m} /$ $z 716.3792[\mathrm{M}+\mathrm{Na}]^{+}$in the HRESITOFMS, corresponding to the molecular formula $\mathrm{C}_{41} \mathrm{H}_{51} \mathrm{~N}_{5} \mathrm{O}_{5}$. Its ${ }^{1} \mathrm{H}$ and ${ }^{13} \mathrm{C}$ NMR data in $\mathrm{CDCl}_{3}$ (Table 1) showed signals similar to those observed for compounds 1 and 2 in the same NMR solvent, except for one fewer methylene carbon and the additional methyl $\left(\delta_{\mathrm{C}} 19.5\right)$ and methine resonances $\left(\delta_{\mathrm{C}} 78.9\right)$ observed in the DEPT spectra for 3. Similar to those of $\mathbf{1}$, the observed fragment peaks at $\mathrm{m} / \mathrm{z} 636$ and 169 in the EIMS data of 3 suggest the presence of phenylalanine and a 5-(sec-butyl)-1,2-dimethylimidazolidin-4-one as the respective exocyclic units (Fig. 3), which is supported by a molecular mass 14 amu greater than that of 1 . The NOE associations of NH-25 $\left(\delta_{\mathrm{H}} 8.73, \mathrm{~d}, J=8.4 \mathrm{~Hz}\right)$ to $\mathrm{H}-9\left(\delta_{\mathrm{H}} 6.17, \mathrm{~d}, J\right.$ $=7.1 \mathrm{~Hz})$ and $\mathrm{H}-28 \mathrm{a}\left(\delta_{\mathrm{H}} 2.29\right.$, brt, $\left.J=12.6 \mathrm{~Hz}\right)$, of $\mathrm{H}-41\left(\delta_{\mathrm{H}} 2.41\right.$, $\mathrm{q}, J=5.4 \mathrm{~Hz})$ to $\mathrm{H}-27\left(\delta_{\mathrm{H}} 3.49\right.$, dd, $\left.J=11.9,4.4 \mathrm{~Hz}\right), \mathrm{H}-30\left(\delta_{\mathrm{H}}\right.$ 6.93 , dd, $J=7.6,1.1 \mathrm{~Hz})$, and $\mathrm{N}-\mathrm{CH}_{3}\left(\delta_{\mathrm{H}} 1.85\right)$, and of the latter $\mathrm{N}-\mathrm{CH}_{3}$ to $\mathrm{H}-35\left(\delta_{\mathrm{H}} 2.57 \mathrm{brs}\right)$, together with connectivities of $\mathrm{H}$ 28 to $\mathrm{C}-30\left(\delta_{\mathrm{C}} 129.2\right)$, of $\mathrm{N}-\mathrm{CH}_{3}$ to $\mathrm{C}-41\left(\delta_{\mathrm{C}} 78.9\right)$ and $\mathrm{C}-35\left(\delta_{\mathrm{C}}\right.$ 71.0), and of $\mathrm{H}-35$ to $\mathrm{C}-36\left(\delta_{\mathrm{C}} 36.5\right)$ in the HMBC spectrum also supported the linkage between the acyclic part and the macrocyclic ring (Fig. 2). The NOESY associations of NH-6 $\left(\delta_{\mathrm{H}} 5.92, \mathrm{~d}, J\right.$ $=8.0 \mathrm{~Hz}) / \mathrm{H}-8$ and $\mathrm{H}-9 / \mathrm{H}-16\left(\delta_{\mathrm{H}} 7.40, \mathrm{dd}, J=8.4,2.1 \mathrm{~Hz}\right)$ confirmed the location of the phenylalanine unit next to the $p$ oxystyrylamine moiety and the isoleucine fragments in the macrocyclic system. The significantly different C-27 $\left(\delta_{\mathrm{C}} 63.0\right)$ and C-41 $\left(\delta_{\mathrm{C}} 78.9\right)$ chemical shifts compared to those of $1(\mathrm{C}-27$, $\delta_{\mathrm{C}} 53.4$ and $\left.\mathrm{C}-41,66.3\right)$ and $2\left(\mathrm{C}-27, \delta_{\mathrm{C}} 54.7\right)$ could be attributed to the presence of the $\mathrm{C}-41$ methyl group. However, the existing data did not permit the establishment of the configuration at C41. Thus, the structure of 3 , cambodine F, was deduced as a new member of the 5(14)-scutianine A-type cyclopeptides possessing a 5-(sec-butyl)-1,2-dimethylimidazolidin-4-one moiety.

The $J$ values of $\mathrm{H}-1$ and $\mathrm{H}-2$ ranging from 7.1-7.4 Hz accounted for the $Z$ geometry of the double bond in compounds 1-3. The intense negative $(236 \mathrm{~nm})$ and weak positive $(283 \mathrm{~nm})$ Cotton effects present in the CD spectrum of $\mathbf{1}$, similar to those of 2 and 3 , and indicative of the $(5 S, 8 S, 9 S)$ configuration. ${ }^{32}$ The $\mathrm{H}-8 / \mathrm{H}-9$ vicinal coupling constants of $8.1 \mathrm{~Hz}$ for $1,6.7$ for 2 , and 7.1 for 3 and the relatively shielded shift of the ${ }^{13} \mathrm{C}$ NMR resonance at approximately $\delta_{\mathrm{C}} 81 \mathrm{ppm}$ for C-9 permitted assignment of the erythro, i.e., $(8 S, 9 S)$ configuration. ${ }^{13}$ The ${ }^{13} \mathrm{C}$ NMR chemical shifts of the phenylalanine and the $N$-methyl isoleucine terminal amino acid units for 1-3, particularly those of stereocenters [1: $\delta_{\mathrm{C}} 53.4(\mathrm{C}-27), 69.7$ (C-35); 2: $\delta_{\mathrm{C}} 53.0$ (C-27), 69.1 $(\mathrm{C}-35) ; 3: \delta_{\mathrm{C}} 63.0$ (C-27), 71.0 (C-35)] were comparable, except for $\mathrm{C}-27$ in 3 as indicated above, with the same terminal dipeptide in paliurine $\mathrm{B}$ [ $\delta_{\mathrm{C}} 51.5$ (C-27), 69.9 (C-35)], a 13-membered ring cyclopeptide obtained from Paliurus ramossisimus. ${ }^{35}$ The stereochemical assignment of the exocyclic dipeptide in paliurine $\mathrm{B}$ was determined by the ${ }^{13} \mathrm{C}$ NMR data comparison with those of the comparable synthesized model dipeptide-LPhe(OMe)-L-Ile $\left(\mathrm{NMe}_{2}\right),{ }^{35}$ the $\mathrm{L}$ amino acids, or $27 S$ and $35 S$, in the acyclic part attached to the macrocycles in 1-3 were then suggested, though the DD-dipeptide cannot be ruled out due to no NMR information available. Furthermore, amino acids in Rhamnaceous cyclopeptide alkaloids generally present in $\mathrm{L}^{-}$ form whilst the D-amino acid only rarely found. For instances, the D-erythro $(8 R, 9 R)$ of scutianine $\mathrm{E},{ }^{36}$ and D-threo $(8 R, 9 S)$ of scutianene $\mathrm{L}^{37}$ were isolated from Scutia buxifolia; whereas epimauritine A and its $N$-oxide obtained from $Z$. apetala showed the $R$-configuration at the terminal unit. ${ }^{38}$ Formation of the imidazolidinone ring in cyclopeptide has been implicated from the reaction between the amino acid residue and aldehyde. ${ }^{34,39}$ The imidazolidinone ring in compounds $\mathbf{1}$ and $\mathbf{3}$ could therefore arise through the condensation of 2 with the respective corresponding carbonyl compounds without an alteration in the amino acid stereocenter.

The two diagnostic Cotton effect bands at about 240 (intense negative) and $280 \mathrm{~nm}$ (weak positive) displayed in the ECD spectrum which could be attributed to the transition of $\mathrm{C}=\mathrm{C}$ double bond conjugation with benzene ring or adjacent amide group, and characterized for the existence of $L$-amino acids in the 14-membered ring cyclopeptide..$^{32,40,41}$ Comparison of the experimental ECD spectrum of 1 to the qualitative calculated ECD data of $(5 S, 8 S, 9 S, 17 S, 27 S, 35 S, 36 S)-\mathbf{1}$ and the $(5 R, 8 R, 9 R, 17 R, 27 R, 35 R, 36 R)-\mathbf{1}$ (Fig. $4 \mathrm{~A})$, indicated 1 to be in agreement with that of all $S$ configuration on the amino acid residues. Calculation of the ECD spectra of individual epimer of 1 were also performed (Fig. 4B) and revealed that the major Cotton effect contribution with opposite sign observed at the band near $238 \mathrm{~nm}$ for $9 S / 9 R$ and at around $245 \mathrm{~nm}$ for $8 S / 8 R$ epimer pair. Similar Cotton effects were found for compounds 2 (negative $236 \mathrm{~nm}$ and positive $283 \mathrm{~nm}$ bands) and 3 (negative $236 \mathrm{~nm}$ and positive $282 \mathrm{~nm}$ bands) and comparable to the theoretical ECD ones (Fig. 4C) allowed the same absolute configuration assignment as for $\mathbf{1}$. From these evidences, including their negative specific rotations, the stereochemical structures of compounds 1-3 were then deduced.

Compound 4, a minor compound from the same fraction of compound 1, was isolated as a colourless amorphous solid and given a molecular formula $\mathrm{C}_{37} \mathrm{H}_{36} \mathrm{~N}_{4} \mathrm{O}_{5}$, as deduced from its positive ion HRESITOFMS at $m / z$ 617.2751 $[\mathrm{M}+\mathrm{H}]^{+}$. The ${ }^{13} \mathrm{C}$ NMR and DEPT spectra $\left(\mathrm{CDCl}_{3}\right)$ disclosed 37 carbon resonances, consisting of an $N$-methyl $\left(\delta_{\mathrm{C}} 39.8\right)$, two methylenes $\left(\delta_{\mathrm{C}}\right.$ $37.5,67.1$ ), 23 methines (two olefinic at $\delta_{\mathrm{C}} 121.2,125.2$, two oxymethine at $\delta_{\mathrm{C}} 73.1,81.6,19$ aromatic at $\delta_{\mathrm{C}} 121.9,123.2$, $126.3,126.9 \times 2,128.2 \times 4,128.6 \times 2,128.7 \times 3,129.1 \times 3$, and $130.2)$, four aromatic quaternary $\left(\delta_{\mathrm{C}} 131.9,136.0,138.1,139.0\right)$, an oxygenated tertiary $\left(\delta_{\mathrm{C}} 155.3\right)$, three amide carbonyls $\left(\delta_{\mathrm{C}}\right.$ $167.7,167.8$ and 172.1) and no signal observed in the aliphatic region (Table 2, Fig. 1). A $1 \mathrm{D}$ and $2 \mathrm{D}$ NMR extensive data analysis in addition to a comparison with previously described values evidenced the spin system of a $p$-oxystyrylamine, a $\beta$ hydroxyphenylalanine, a phenylalanine, and a 1methylimidazolidin-4-one, which is derived from the phenylalanine of the 4(14)-integerrine-type cyclopeptide alkaloid. Interestingly, a broad three-bond singlet at $\delta_{\mathrm{H}} 1.59$ was assigned to the styrylamine double bond $\mathrm{H}-1, \mathrm{H}-2$, and $\mathrm{NH}-3$ by the $\mathrm{HMBC}$ of $\mathrm{H}-1$ to $\mathrm{C}-2\left(\delta_{\mathrm{C}} 125.5\right), \mathrm{C}-14\left(\delta_{\mathrm{C}} 131.9\right)$ and $\mathrm{C}-15\left(\delta_{\mathrm{C}} 131.0\right)$ and of H-2 to C-14 and the NOESY of H-3 to H-5 $\left(\delta_{\mathrm{H}} 4.51\right.$, brt, $J=8.1$ 
A
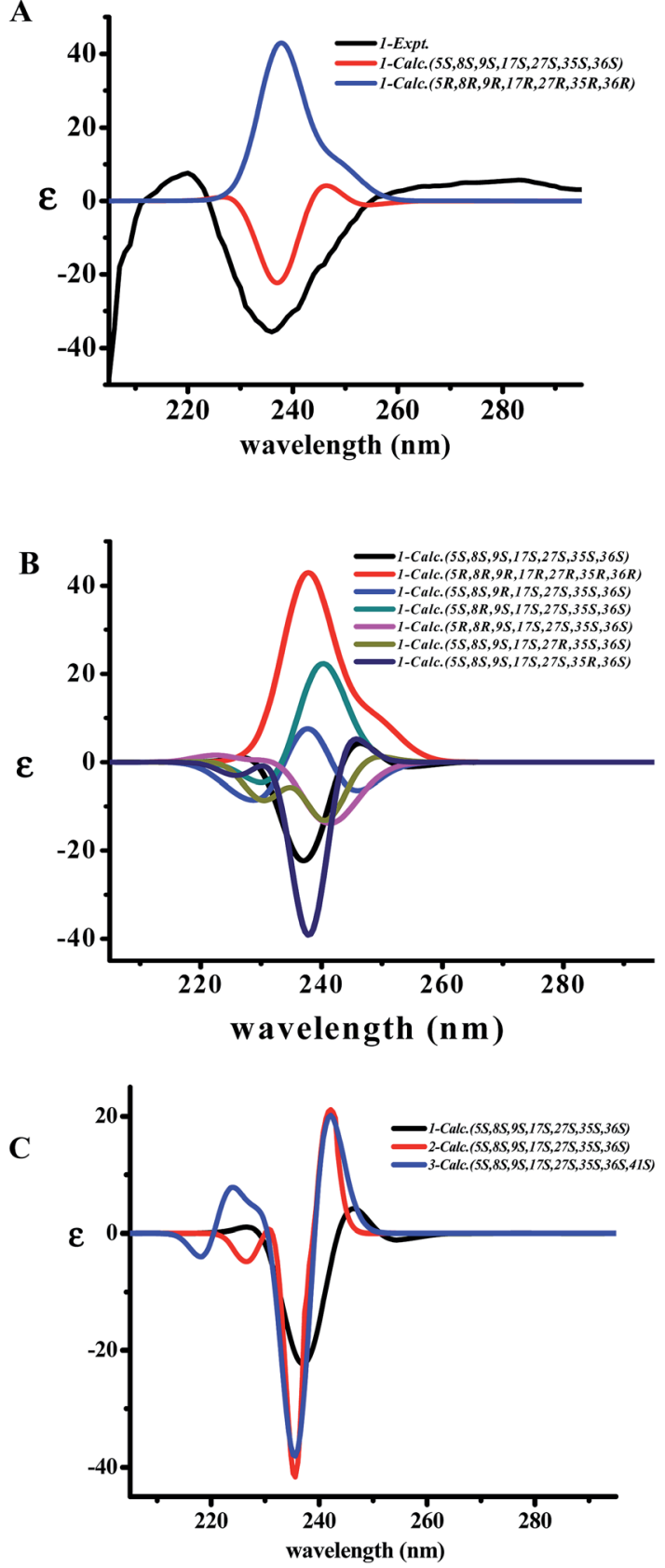

Fig. 4 The superimpose of calculated ECD of (5S,8S,9S,17S,27S,35S,36S)-1 and the $(5 R, 8 R, 9 R, 17 R, 27 R, 35 R, 36 R)-1$ compared to the observed ECD spectra $(A)$; the ECD spectra of each epimer for 1 were also calculated for the stereochemical structures (B) and the theoretical spectra of 1-3 were calculated at the M062X/6$311 \mathrm{G}(\mathrm{d}, \mathrm{p}) / / \mathrm{M} 062 \mathrm{X} / 6-311 \mathrm{G}$ level of theory in the $\mathrm{MeOH}$ solution and their superimpose ECD (C).

$\mathrm{Hz}$ ) connectivities (Fig. 2). The presence of the $\beta$-hydroxyphenylalanine was characterized by the $\mathrm{OH}$ absorption frequency at $3447 \mathrm{~cm}^{-1}$ in the IR data, along with the correlations from the oxymethine doublet resonance $\mathrm{H}-17\left(\delta_{\mathrm{H}} 4.94, J=\right.$ $7.6 \mathrm{~Hz}$ ) to a carbonyl carbon $\mathrm{C}-4$ at $\delta_{\mathrm{C}} 167.8$ and an aromatic carbon at $\delta_{\mathrm{C}} 126.9(\mathrm{C}-18)$ in the HMBC spectrum, in addition to the NOESY connectivities of $\mathrm{H}-17$ to NH-6 $\left(\delta_{\mathrm{H}} 6.37\right.$, brd, $J=8.5$
$\mathrm{Hz}$ ). As for other cyclopeptides, the $\mathrm{HMBC}$ correlations of $\mathrm{H}-1$ to C-14 and C-15, of H-5 to CO-7 $\left(\delta_{\mathrm{C}} 167.7\right)$, and of $\mathrm{H}-9\left(\delta_{\mathrm{H}} 5.90, \mathrm{~d}, J\right.$ $=7.3 \mathrm{~Hz})$ to $\mathrm{C}-22\left(\delta_{\mathrm{C}} 128.2\right)$ and of the NOESY interactions of $\mathrm{H}-$ 5 to $\mathrm{NH}-3$ and of $\mathrm{H}-9$ to $\mathrm{H}-16\left(\delta_{\mathrm{H}} 7.29\right)$ suggested that the phenylalanine and $\beta$-hydroxyphenylalanine were placed next to each other and attached to the oxystyrylamine in the cyclic ring. A 5-benzyl-1-methylimidazolidin-4-one group was determined by the analysis of the $1 \mathrm{D}$ and $2 \mathrm{D}$ NMR spectra of 4 : the presence of the two diastereotopic protons at $\delta_{\mathrm{H}} 3.66$ and 2.70 (each d, $J=$ $4.3 \mathrm{~Hz}, \mathrm{H}-34 \mathrm{a}$ and $\mathrm{H}-34 \mathrm{~b}), \delta_{\mathrm{C}} 67.1$; an $N$-methyl $\left(\delta_{\mathrm{H}} 1.64, \mathrm{~s}\right)$, a ring multiplet methine proton resonance at $\delta_{\mathrm{H}} 2.69(\mathrm{H}-27), \delta_{\mathrm{C}}$ 66.5; a benzyl group $\left(\delta_{\mathrm{H}} 2.67, \mathrm{~m}, \mathrm{H}-28, \delta_{\mathrm{C}} 37.5 ; \delta_{\mathrm{H}} 7.24-7.47\right.$, $\left.\mathrm{ArH}, \delta_{\mathrm{C}} 126.3-138.1\right)$ and an amide carbonyl at $\delta_{\mathrm{C}} 172.1(\mathrm{C}-26)$. A series of connectivities was observed: a diastereotopic proton at $\delta_{\mathrm{H}} 3.66$ showed NOESY correlations to $\mathrm{H}-9$ and $\mathrm{H}-27$ and of $\mathrm{H}-27$ to $\mathrm{N}-\mathrm{CH}_{3}$, and the $\mathrm{HMBC}$ connections of $\mathrm{H}-8\left(\delta_{\mathrm{H}} 4.87, \mathrm{~d}, J=7.3\right.$ $\mathrm{Hz}$ ) to carbonyl carbon C-26, of $\mathrm{H}-27$ to C-29 and of $\mathrm{H}-28$ to C-30 showed that the imidazolidin-4-one ring was connected to the macrocyclic ring at C-8 of the phenylalanine. The structure of $\mathbf{4}$, cambodine B, was thus elucidated as a new member of the 4(14)-integerrine-type cyclopeptides.

Compound 5 was also obtained as a colourless amorphous solid from the detannified EtOAc-soluble fraction of $Z$. cambodiana. Its molecular formula was deduced as $\mathrm{C}_{31} \mathrm{H}_{40} \mathrm{~N}_{4} \mathrm{O}_{4}$ from its positive ion HRESITOFMS at $m / z$ 555.2929 $[\mathrm{M}+\mathrm{H}]^{+}$. A detailed analysis of the 1D, DEPT and 2D spectroscopic data suggested that 5 also possessed a 4(14)-type cyclopeptide containing the same macrocyclic ring and terminal unit as for $\mathbf{1}$ (Fig. 1). The main differences in their ${ }^{13} \mathrm{C}$ NMR data (Table 2) are the absence of the intermediate phenylalanine resonances in 5 compared to that of 1 . A series of correlations of $\mathrm{H}-8\left(\delta_{\mathrm{H}}\right.$ $5.09, \mathrm{~d}, J=7.6 \mathrm{~Hz})$ to $\mathrm{C}-26\left(\delta_{\mathrm{C}} 172.8\right)$, of $\mathrm{H}-33 \mathrm{a}\left(\delta_{\mathrm{H}} 3.83\right.$, brd, $J=$ $3.9 \mathrm{~Hz})$ to $\mathrm{C}-27\left(\delta_{\mathrm{C}} 70.4\right)$, and of $\mathrm{H}-27\left(\delta_{\mathrm{H}} 2.48, \mathrm{~d}, J=2.6 \mathrm{~Hz}\right)$ to CO-26, C-29 $\left(\delta_{\mathrm{C}} 24.7\right)$ and C-31 $\left(\delta_{\mathrm{C}} 14.7\right)$ displayed in the HMBC spectrum, together with the interactions of $\mathrm{H}-33$ a to $\mathrm{H}-9\left(\delta_{\mathrm{H}}\right.$ $5.99, \mathrm{~d}, J=7.6 \mathrm{~Hz}), \mathrm{H}-22^{\prime}\left(\delta_{\mathrm{H}} 7.52\right.$, dd, $\left.J=7.7,1.9 \mathrm{~Hz}\right)$ and $\mathrm{N}-$ $\mathrm{CH}_{3}\left(\delta_{\mathrm{H}} 2.11\right)$ and of $\mathrm{H}-27$ to $\mathrm{N}-\mathrm{CH}_{3}, \mathrm{H}-29\left(\delta_{\mathrm{H}} 1.08, \mathrm{~m}\right)$ and $\mathrm{H}-31$ $\left(\delta_{\mathrm{H}} 0.55, \mathrm{~d}, J=6.8 \mathrm{~Hz}\right)$ observed in the NOESY spectrum indicated that the 5-(sec-butyl)-1-methylimidazolidin-4-one ring was the end fragment of the system (Fig. 2). The structure of $\mathbf{5}$, cambodine $\mathrm{D}$, was thus established as an additional member of the 4(14)-integerrine-type cyclopeptides.

Compound 6 was isolated as colourless needles and displayed a sodium adduct molecular ion $[\mathrm{M}+\mathrm{Na}]^{+}$at $m / z 623.2606$ in the HRESITOFMS, corresponding to a molecular formula of $\mathrm{C}_{37} \mathrm{H}_{36} \mathrm{~N}_{4} \mathrm{O}_{4}$. Its ${ }^{1} \mathrm{H}$ and ${ }^{13} \mathrm{C}$ NMR data (Table 2, Fig. 1) were almost identical to those of compound 4, with the difference being the presence of the two germinal proton resonances at $\delta_{\mathrm{H}}$ $3.40(\mathrm{dd}, J=14.8$ and $3.4 \mathrm{~Hz}, \mathrm{H}-17 \mathrm{a})$ and $\delta_{\mathrm{H}} 2.61(\mathrm{dd}, J=14.8$ and $11.2 \mathrm{~Hz}, \mathrm{H}-17 \mathrm{~b})\left(\delta_{\mathrm{C}} 36.7\right)$ of the ring-bound amino acid in 6 , instead of the oxymethine signal in 4. In the HMBC spectrum, the connectivities of the resonance at $\delta_{\mathrm{H}} 2.61$ to $\mathrm{C}-5\left(\delta_{\mathrm{C}} 55.4\right)$ and a carbonyl carbon at $\delta_{\mathrm{C}} 166.5(\mathrm{C}-4)$, of NH-6 at $\delta_{\mathrm{H}} 6.40(\mathrm{~d}, J=$ $8.1 \mathrm{~Hz})$ to $\mathrm{C}-5$, and of an aromatic signal at $\delta_{\mathrm{H}} 7.09(\mathrm{~d}, J=8.7 \mathrm{~Hz}$, $\mathrm{H}-18)$ to $\mathrm{C}-17$ confirmed that the phenylalanine was bound to $p$ oxystyrylamine and $\beta$-hydroxyphenylalanine in the cyclic structure. Its EIMS spectrum showed the base peak at $\mathrm{m} / \mathrm{z} 509$ and 
Table $2{ }^{1} \mathrm{H}$ and ${ }^{13} \mathrm{C}$ NMR spectroscopic data for compounds 4-6 in $\mathrm{CDCl}_{3}$

\begin{tabular}{|c|c|c|c|c|c|c|}
\hline \multirow[b]{2}{*}{ No. } & \multicolumn{3}{|l|}{$\delta_{\mathrm{C}}$} & \multicolumn{3}{|l|}{$\delta_{\mathrm{H}}$} \\
\hline & 4 & 5 & 6 & 4 & 5 & 6 \\
\hline 1 & 121.2 & 117.8 & 116.9 & 6.59 , brs & $6.46, \mathrm{~d}(7.6)$ & $6.47, \mathrm{~d}(7.6)$ \\
\hline 2 & 125.2 & 125.4 & 125.6 & 6.59, brs & 6.66, dd $(9.5,7.6)$ & 6.37, brt $(7.6)$ \\
\hline 4 & 167.8 & 166.8 & 166.5 & & & \\
\hline 5 & 57.5 & 59.3 & 55.4 & 4.51, brt $(8.1)$ & $4.01, \mathrm{dd}(8.5,4.4)$ & 4.44, ddd $(11.2,8.1,3.4)$ \\
\hline 7 & 167.7 & 168.2 & 168.1 & & & \\
\hline 8 & 57.8 & 57.9 & 57.6 & $4.87, \mathrm{~d}(7.3)$ & $5.09, \mathrm{~d}(7.6)$ & $4.95, \mathrm{~d}(7.2)$ \\
\hline 9 & 81.6 & 80.7 & 81.7 & $5.90, \mathrm{~d}(7.3)$ & $5.99, \mathrm{~d}(7.6)$ & $5.91, \mathrm{~d}(7.2)$ \\
\hline 11 & 155.3 & 155.0 & 155.4 & & & \\
\hline 12 & 123.2 & 123.3 & 123.2 & 7.26 , overlap & 7.32, overlap & 7.34, overlap \\
\hline 13 & 130.2 & 130.2 & 130.4 & 7.05, dd $(6.8,1.3)$ & $7.13, \mathrm{t}(7.1)$ & 7.14 , overlap \\
\hline 14 & 131.9 & 132.3 & 132.2 & & & \\
\hline 15 & 131.0 & 131.6 & 131.7 & $7.10, \mathrm{dd}(6.8,1.3)$ & $7.10, \mathrm{t}(7.1)$ & 7.14, overlap \\
\hline 16 & 121.9 & 122.8 & 122.5 & 7.29 , overlap & 7.34 , overlap & 7.34 , overlap \\
\hline 17 & 73.1 & 34.4 & 36.7 & $4.94, \mathrm{~d}(7.6)$ & $2.16, \mathrm{~m}$ & $\begin{array}{l}\text { a } 3.40, \text { dd }(14.8,3.4) \\
\text { b } 2.61, \text { dd }(14.8,11.2)\end{array}$ \\
\hline $18 \mathrm{a}$ & 139.0 & & 136.9 & & & \\
\hline $18,18^{\prime}$ & 126.9 & 23.9 & 128.8 & 7.24, overlap & $1.17, \mathrm{~m}, 0.88, \mathrm{~m}$ & $7.09, \mathrm{~d}(8.7)$ \\
\hline $19,19^{\prime}$ & 128.7 & 11.7 & 128.5 & 7.03 , overlap & $0.81, \mathrm{t}(6.3)$ & 7.19, brt $(8.7)$ \\
\hline 20 & 128.7 & 16.5 & 127.1 & 7.24 , overlap & $0.70, \mathrm{~d}(6.8)$ & 7.07 , overlap \\
\hline 21 & 136.0 & 136.2 & 136.0 & & & \\
\hline $22,22^{\prime}$ & 128.2 & 128.2 & 128.2 & 7.46, overlap & $7.52, \mathrm{dd}(7.7,1.9)$ & 7.46 , overlap \\
\hline $23,23^{\prime}$ & 128.6 & 128.8 & 128.8 & 7.19 , overlap & $7.39, \mathrm{t}(6.9)$ & 7.39 , overlap \\
\hline 24 & 129.1 & 129.2 & 129.0 & 7.39 , overlap & 7.41 , overlap & 7.11 , overlap \\
\hline 26 & 172.1 & 172.8 & 172.3 & & & \\
\hline 27 & 66.5 & 70.4 & 66.1 & $2.69, \mathrm{~m}$ & $2.48, \mathrm{~d}(2.6)$ & $2.39, \mathrm{~m}$ \\
\hline 28 & 37.5 & 35.8 & 37.6 & $2.67, \mathrm{~m}$ & $1.29, \mathrm{~m}$ & $\begin{array}{l}\text { a } 2.66, \text { dd }(13.8,8.9) \\
\text { b } 1.72, \text { dd }(13.8,11.2)\end{array}$ \\
\hline 29 & 138.1 & 24.7 & 138.2 & & $1.08, \mathrm{~m}$ & \\
\hline 30 & 129.1 & 11.9 & 129.1 & 7.39, overlap & $0.77, \mathrm{t}(7.4)$ & 7.00, brd $(6.1)$ \\
\hline 31 & 128.2 & 14.7 & 128.2 & 7.24 , overlap & $0.55, \mathrm{~d}(6.8)$ & 7.26 , overlap \\
\hline 32 & 126.3 & & 126.2 & 7.47 , overlap & & 7.22 , overlap \\
\hline 33 & & 67.6 & & & $\begin{array}{l}\text { a } 3.83, \text { br d (3.9) } \\
\text { b } 3.22 \text {, br d }(3.9)\end{array}$ & \\
\hline 34 & 67.1 & & 67.0 & $\begin{array}{l}\text { a } 3.66, \mathrm{~d}(4.3) \\
\text { b } 2.70, \mathrm{~d}(4.3)\end{array}$ & & $\begin{array}{l}\text { a } 3.56, \mathrm{~d}(4.7) \\
\text { b } 2.43, \mathrm{~d}(4.7)\end{array}$ \\
\hline 3-NH & & & & 6.59, brs & $6.50, \mathrm{~d}(9.5)$ & $6.51, \mathrm{~d}(9.9)$ \\
\hline 6-NH & & & & 6.37, brd $(8.5)$ & $5.81, \mathrm{~d}(8.5)$ & $6.40, \mathrm{~d}(8.1)$ \\
\hline $\mathrm{NMe}$ & 39.8 & 41.1 & 39.5 & $1.64, \mathrm{~s}$ & $2.11, \mathrm{~s}$ & $1.48, \mathrm{~s}$ \\
\hline
\end{tabular}

a fragment ion peak at $m / z 227$, indicating the existence of a 5benzyl-1-methylimidazolidin-4-one unit as the end residue. This was supported by the presence of two geminal protons at $\delta_{\mathrm{H}} 3.56$ (d, $J=4.7 \mathrm{~Hz}, \mathrm{H}-34 \mathrm{a}$ ) and $\delta_{\mathrm{H}} 2.43$ (d, $\left.J=4.7 \mathrm{~Hz}, \mathrm{H}-34 \mathrm{~b}\right)$, a singlet $\mathrm{N}-\mathrm{CH}_{3}$ at $\delta_{\mathrm{H}} 1.48\left(\delta_{\mathrm{C}} 39.5\right)$, and a multiplet methine resonance of $\mathrm{H}-27$ at $\delta_{\mathrm{H}} 2.39\left(\delta_{\mathrm{C}} 66.1\right)$, in addition to a carbonyl carbon signal at $\delta_{\mathrm{C}} 172.3(\mathrm{C}-26)$ and a benzyl group in its NMR data. Compound 6 exhibited similar 2D NMR (HMBC and NOESY) correlations, both at the cyclic and the terminal ring, to those of compound 4. A remarkable upfield-shifted $\mathrm{N}-\mathrm{CH}_{3}$ resonance at $\delta_{\mathrm{H}} 1.48$ in 6 could be due to an anisotropic effect arising from the benzyl group when compared with compound $5\left(\delta_{\mathrm{H}} 2.11\right)$ that has a sec-butyl moiety. The structure of 6 , cambodine E, was thus elucidated as an analogue of cyclopeptide 4 .

The X-ray crystal structure of $\mathbf{6}$ supported a skeleton comprised of a $Z$-styrylamine, two phenylalanines and a 5benzyl-1-methylimidazolidin-4-one subunit and also confirmed

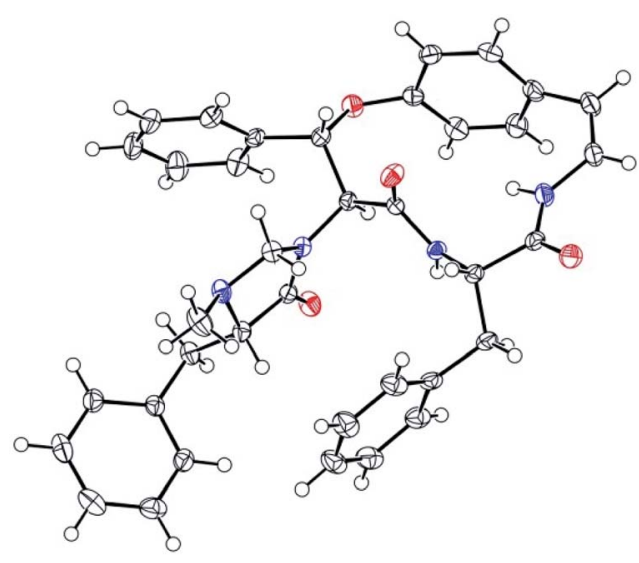

Fig. 5 ORTEP plot of the X-ray crystal structure for compound 6. 
the trans arrangement between $\mathrm{H}-8$ and $\mathrm{H}-9$ displayed in the macrocyclic motif (Fig. 5). The ECD spectrum of 6, as well as the spectra of the other cyclopeptides indicated above, provided the $5 S, 8 S$ and $9 S$ configuration assignments at the amino acid residues of the cyclic part. The imidazolidinone configuration at $27 S$ was then subsequently decisively assigned. The similarities in the NMR data on the terminal ring of 6 compared with those of 4 and 5, associated with the calculated ECD spectra of 4-6 (Fig. 6) were in accordance with those observed ECD value have led to the conclusion that cyclopeptides 4-6 contribute the same stereochemistry both at the macrocyclic ring and at the imidazolidinone unit.

The two cyclopeptides 7 and 8 were identified as the 4(14)type cyclopeptide alkaloids, frangufoline ${ }^{19}$ or daechuine $\mathrm{S}^{32}$ or sanjoinine $\mathrm{A}^{42}$ and lotusanine $\mathrm{B},{ }^{20}$ respectively, by detailed examinations of their $1 \mathrm{D}$ and 2D NMR and MS spectroscopic data along with comparison to their reported values (Fig. 1, ESI $\dagger$ ). The ${ }^{13} \mathrm{C}$ NMR resonances of the chiral carbons observed for 7 were in good agreement with the literature data for frangufoline whose stereochemistry was proven to be all $S$ configurations by the analysis of each amino acid residue in its acid hydrolysate and confirmed by total synthesis. ${ }^{19,43}$ The ECD spectrum of 7 exhibited strong negative (239 $\mathrm{nm}$ ) and positive $(287 \mathrm{~nm})$ Cotton effects that also supported the same $(5 S, 8 S, 9 S)$-configurations at the 14-membered ring and its negative specific rotation $\left([\alpha]_{\mathrm{D}}^{39}-218.5\right)$, which led to the conclusion that 7 has the same structure and configuration as the reported frangufoline. In a manner similar to that observed for the other cyclopeptide alkaloids, the ${ }^{13} \mathrm{C}$ NMR chemical shifts at the chiral carbons of $\mathbf{8}$ are almost identical to those of amaiouine, a structurally related cyclopeptide isolated from Amaioua guianensi that was different from 8 by having a phenylalanine in place of a leucine amino acid in the macrocyclic ring. The absolute configurations of amaiouine were established to be all $S$ according to its X-ray crystallographic data. ${ }^{44}$ Therefore, our observed ECD spectrum (strong negative and weak positive bands at 237 and $283 \mathrm{~nm}$, respectively) was also in accordance with the all $S$ configurations at the amino acid residues for $\mathbf{8}$. It should be noted that

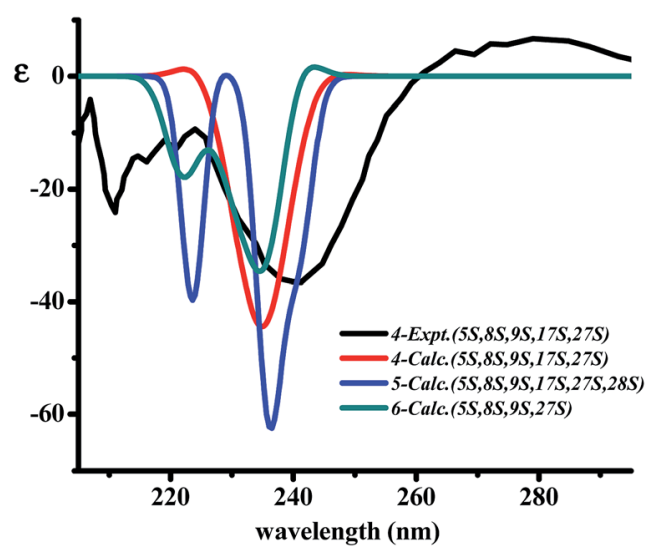

Fig. 6 The superimpose of calculated ECD for 4-6 in comparison to the observed ECD spectra of 4 . compound 8 showed negative optical activity, although the previously reported lotusanine B was a racemate. Frangufoline has been isolated from many plants belonging to the Rhamnaceae, Celastraceae and Sterculiaceae families, ${ }^{32}$ whereas lotusanine B was obtained from Ziziphus lotus. ${ }^{20}$

The in vitro antimalarial effect against Plasmodium falciparum of compounds 1-8 was evaluated. ${ }^{45,46}$ Only cambodine F (3) showed interesting antiplasmodial activity, with an $\mathrm{IC}_{50}$ of $6.09 \mu \mathrm{M}$, which could be accounted for by the importance of the rare 5-(sec-butyl)-1,2-dimethylimidazolidin-4-one unit. All compounds were considered inactive against Mycobacterium tuberculosis, ${ }^{47}$ except for cambodines B (4) and C (2), and lotusanine B (8) which showed weak activity, with MICs of 81.0, 149.7 and $93.8 \mu \mathrm{M}$, respectively. All compounds were also tested in vitro for cytotoxic properties against three human cancer cell lines: epidermoid carcinoma of the mouth (KB), breast cancer (BC-1), and small cell lung cancer (NCI-H187) cells. $^{48}$ Of the tested compounds, cambodine A (1) was moderately active against the $\mathrm{BC}$ cells at $\mathrm{IC}_{50} 11.1 \mu \mathrm{M}$, and cambodines $\mathrm{C}-\mathrm{E}(\mathbf{2}, \mathbf{5}, \mathbf{6})$ exhibited weak activity towards the NCI cells, with $\mathrm{IC}_{50}$ values of $20.7,36.7$ and $35.0 \mu \mathrm{M}$, respectively. None of the compounds were toxic to the non-cancerous Vero cells, except for $\mathbf{6}$, which showed weak action with an $\mathrm{IC}_{50}$ of $48.2 \mu \mathrm{M}$. To date, only two studies on the in vitro cytotoxicity of natural rhamnaceous cyclopeptide alkaloids have been reported, ${ }^{38,49}$ although the weak activity of some representative synthetic 13- and 15-membered ring cyclopeptides was described recently. ${ }^{50}$

\section{Experimental section}

\section{General experimental procedure}

Melting points were determined using a Griffin melting point apparatus and are uncorrected. Optical rotations at the sodium D line were measured on a JASCO-1020 digital polarimeter. ECD spectra were recorded on a Jasco J-810 spectropolarimeter. IR spectra were measured on a Perkin-Elmer FT-IR Spectrum BX spectrophotometer, with $\nu_{\max }$ given in $\mathrm{cm}^{-1}$. NMR spectra were measured at $300 \mathrm{MHz}\left({ }^{1} \mathrm{H}\right)$ and $75 \mathrm{MHz}\left({ }^{13} \mathrm{C}\right)$ on a Bruker AVANCE 300 FT-NMR spectrometer using TMS or residual nondeuterated solvent signals as an internal standard $\left(\mathrm{CDCl}_{3}: \delta_{\mathrm{H}}\right.$ 7.24, $\delta_{\mathrm{C}}$ 77.00; DMSO- $d_{6}: \delta_{\mathrm{H}} 2.49$ and $\delta_{\mathrm{C}} 39.5$ for ${ }^{1} \mathrm{H}$ and ${ }^{13} \mathrm{C} \mathrm{NMR}$ spectra, respectively). EIMS were recorded on a Thermo Finnigan Polaris Q mass spectrometer at $70 \mathrm{eV}$ (probe). ESIMS were obtained on a Finnigan LC-Q mass spectrometer. The HRESITOFMS were measured on a Bruker micrOTOF-QII mass spectrometer. The X-ray crystallographic data analysis was carried out with a Bruker-Nonius kappaCCD diffractometer with a graphite monochromator, $\operatorname{MoK} \alpha$ radiation $(\lambda=0.71073 \AA)$ at 298(2) K. Silica gel (finer than $0.063 \mathrm{~mm}$, Merck) and Sephadex LH-20 (Pharmacia) were used for column chromatography. TLC analyses were carried out on plates that had been precoated with silica gel $\mathrm{F}_{254}$ from Merck and visualized under a UV light at 254 or $365 \mathrm{~nm}$ and by spraying with $5 \%$ anisaldehyde- $\mathrm{H}_{2} \mathrm{SO}_{4}$ solution followed by heating. 


\section{Plant materials}

Shade-dried root bark of $Z$. cambodiana was collected from Chamni District, Burirum Province, Thailand, in March 2007. The material was identified by James F. Maxwell of the Faculty of Science, Chiang Mai University, Thailand. A voucher specimen (Wichan Wisetsri 002) has been deposited at the Laboratory of the Natural Product Research Unit, Srinakharinwirot University, Thailand.

\section{Extraction and separation}

The powdered root bark of $Z$. cambodiana $(10.0 \mathrm{~kg})$ was extracted successively with EtOAc (20 L x 3) and $\mathrm{MeOH}(20 \mathrm{~L} \times 3)$ at $50{ }^{\circ} \mathrm{C}$ for $48 \mathrm{~h}$ for each solvent. The combined extract was evaporated under reduced pressure at temperature $40-45{ }^{\circ} \mathrm{C}$ to yield EtOAc $(144.7 \mathrm{~g})$ and $\mathrm{MeOH}(1.4 \mathrm{~kg})$ extracts. The crude extract was subjected to chromatographic separation, and only fractions that showed blue spots upon staining with anisaldehyde- $\mathrm{H}_{2} \mathrm{SO}_{4}$ reagent on TLC were selected for further separation and purification. A portion of the EtOAc soluble extract (80 g) was fractionated by quick column chromatography on silica gel (160 g), eluting with a gradient system of hexanes, $\mathrm{CH}_{2} \mathrm{Cl}_{2}$, EtOAc and $\mathrm{MeOH}$ (5\% increment of the more polar component, each 300 $\mathrm{mL}$ ) to provide nine major fractions (Fr. A-I) on the basis of TLC analysis. Fr. F (8.9 g) was separated on a silica gel column (100 g), employing solvent gradient EtOAc- $\mathrm{CH}_{2} \mathrm{Cl}_{2}$ (5: 95-50:50), and eight subfractions (F1-F8) were collected. Subfraction F5 (2.1 g) was further chromatographed on a silica gel column (60 g), eluting with EtOAc- $\mathrm{CH}_{2} \mathrm{Cl}_{2}$ (5:95-50:50), and nine subfractions (F5/1-F5/9) were collected. Subfractions F5/6 (5 mg) and $\mathrm{F} 5 / 7$ (73 $\mathrm{mg})$ were combined and rechromatographed on a silica gel column ( $9 \mathrm{~g})$, eluting with EtOAc- $\mathrm{CH}_{2} \mathrm{Cl}_{2}(1: 10)$, and subfraction 6 was proved to be cambodine A (1) (48 mg). Subfraction $8\left(22 \mathrm{mg}, 50-100 \%(\mathrm{v} / \mathrm{v})\right.$ EtOAc- $\left.\mathrm{CH}_{2} \mathrm{Cl}_{2}\right)$ was further separated on a Sephadex LH-20 column, eluting with $\mathrm{MeOH}$, to give cambodine B (4) (6.6 mg). Subfraction F7 (535 mg) was further chromatographed on a silica gel column (19 g), eluting with a gradient system of hexanes, $\mathrm{CH}_{2} \mathrm{Cl}_{2}$ and $\mathrm{MeOH}$, and six subfractions (F7a-F7f) were collected to give cambodine C (2) (4.4 mg). Subfraction $3(130 \mathrm{mg})$ was further chromatographed on a silica gel column (5 g), eluting with $\mathrm{CH}_{2} \mathrm{Cl}_{2}-\mathrm{MeOH}(80: 20)$ to obtain more of $2(12.8 \mathrm{mg})$.

A portion of the $\mathrm{MeOH}$ extract $(30.7 \mathrm{~g}$ ) was fractionated by quick column chromatography (silica gel, $170 \mathrm{~g}$ ), eluting with EtOAc- $\mathrm{CH}_{2} \mathrm{Cl}_{2}$ (50 : 50), EtOAc, $\mathrm{MeOH}$ and $\mathrm{H}_{2} \mathrm{O}-\mathrm{MeOH}(50: 50)$ to yield four major fractions (Fr. J-M). Fr. J ( $0.8 \mathrm{~g})$ was applied to a silica gel column $(20 \mathrm{~g})$ and eluted with a $\mathrm{MeOH}-\mathrm{CH}_{2} \mathrm{Cl}_{2}$ ( 1 : 99-30 : 70) gradient system to yield 10 subfractions (J1-J10). Subfraction J2 was purified by CC over silica gel (eluted with $\mathrm{MeOH}-\mathrm{CH}_{2} \mathrm{Cl}_{2}, 3: 97-15: 85$ gradient system) followed by a Sephadex LH-20 column (eluted with $\mathrm{MeOH}$ ) to yield 7 (11 mg) as colourless needles. Fr. K (11 g) was chromatographed on a silica gel column (16 g) to give six subfractions (K1-K6). Subfraction K2 (163 mg) was separated on a silica gel column (7 g) eluting with EtOAc- $\mathrm{CH}_{2} \mathrm{Cl}_{2}(5: 95-15: 85)$ to give more of frangufoline (7) (16.3 mg) and lotusanine B (8) (7.5 mg).
Another portion of the $\mathrm{MeOH}$ extract (225 g) was suspended in $1 \% \mathrm{NaCl}(100 \mathrm{~mL})$ and then partitioned with EtOAc $(6 \times 150$ $\mathrm{mL}$ ), combined and concentrated to give a detannified EtOAc soluble fraction $(12.7 \mathrm{~g})$ as a pale brown paste. This detannified EtOAc soluble fraction was chromatographed on a silica gel column (150 g) to give six major fractions (Fr. N-S). Fr. O (1.2 g) was further separated on a gel column $(29 \mathrm{~g})$, eluted with EtOAc$\mathrm{CH}_{2} \mathrm{Cl}_{2}$ (5:95-13:87), to provide 17 subfractions. Compound 5 (29.4 $\mathrm{mg}$ ) was separated after the subfraction $\mathrm{O} 12$ (85 g) was rechromatographed on silica gel ( $8 \mathrm{~g}$ ), eluting with EtOAc$\mathrm{CH}_{2} \mathrm{Cl}_{2}$ (10:90). Subfraction $\mathrm{O} 14$ (203 $\mathrm{mg}$ ) was separated on a Sephadex LH-20 column, eluting with $\mathrm{MeOH}-\mathrm{CH}_{2} \mathrm{Cl}_{2}, 50: 50$ to give compounds $3(7.0 \mathrm{mg})$ and $6(35.2 \mathrm{mg})$.

Cambodine A (1). Colourless amorphous solid, mp 248$249{ }^{\circ} \mathrm{C} ;[\alpha]_{\mathrm{D}}^{38}-162(\mathrm{c} 0.3, \mathrm{MeOH}) ; \operatorname{ECD}(\mathrm{MeOH})(\Delta \varepsilon) 283(+5.71)$, 236 (-35.66), $220(+7.60) \mathrm{nm}$; IR (KBr) $\nu_{\max } 3289,2963,1701$, 1682, 1636, 1508, 1455, 1380, 1241, 1019, $697 \mathrm{~cm}^{-1} ;{ }^{1} \mathrm{H}$ and ${ }^{13} \mathrm{C}$ NMR $\left(\mathrm{CDCl}_{3}\right)$ spectroscopic data, see Table 1; EIMS $\mathrm{m} / \mathrm{z} 680$ (4), 679 (10), 622 (34), 525 (15), 155 (100), 135 (48); positive HRESITOFMS $m / z 680.3808[\mathrm{M}+\mathrm{H}]^{+}$(calcd for $\mathrm{C}_{40} \mathrm{H}_{50} \mathrm{~N}_{5} \mathrm{O}_{5}$, 680.3806).

Cambodine C (2). Colourless amorphous solid, mp 225$227{ }^{\circ} \mathrm{C} ;[\alpha]_{\mathrm{D}}^{38}-199(\mathrm{c} 0.2, \mathrm{MeOH}) ; \mathrm{ECD}(\mathrm{MeOH})(\Delta \varepsilon) 280(+6.44)$, 236 (-41.88), $220(+15.46) \mathrm{nm}$; IR (KBr) $\nu_{\max } 3338,2959,2927$, 2878, 1668, 1642, 1508, 1453, 1221, 1032, $701 \mathrm{~cm}^{-1} ;{ }^{1} \mathrm{H}$ and ${ }^{13} \mathrm{C}$ NMR $\left(\mathrm{CDCl}_{3}\right.$ and DMSO- $\left.d_{6}\right)$ spectroscopic data, see Table 1; positive HRESITOFMS $\mathrm{m} / \mathrm{z} 668.3807[\mathrm{M}+\mathrm{H}]^{+}$(calcd for $\mathrm{C}_{39} \mathrm{H}_{50} \mathrm{~N}_{5} \mathrm{O}_{5}, 668.3811$ ).

Cambodine F (3). Colourless amorphous, mp 216-218 ${ }^{\circ} \mathrm{C}$; $[\alpha]_{\mathrm{D}}^{38}-131$ (c 0.2, MeOH); ECD (MeOH) $(\Delta \varepsilon) 282(+9.76), 236$ (-46.29), $213(-16.80) \mathrm{nm}$; IR (KBr) $\nu_{\max } 3267,2962,2927,1685$, 1647, 1507, 1456, 1337, 1233, 1012, 758, $699 \mathrm{~cm}^{-1} ;{ }^{1} \mathrm{H}$ and ${ }^{13} \mathrm{C}$ NMR $\left(\mathrm{CDCl}_{3}\right)$ spectroscopic data, see Table 1; EIMS m/z 694 (9), 693 (24), 636 (49), 243 (17), 169 (100), 135 (14); positive HRESITOFMS $\mathrm{m} / \mathrm{z} 716.3792[\mathrm{M}+\mathrm{Na}]^{+}$(calcd for $\mathrm{C}_{41} \mathrm{H}_{51} \mathrm{~N}_{5} \mathrm{O}_{5} \mathrm{Na}$, 716.3782).

Cambodine B (4). Colourless amorphous solid, mp 140$141{ }^{\circ} \mathrm{C} ;[\alpha]_{\mathrm{D}}^{39}-107$ (c 0.2, MeOH); ECD $(\mathrm{MeOH})(\Delta \varepsilon) 279(+6.67)$, 240 (-36.46), 224 (-9.30) nm; IR (film) $\nu_{\max } 3447,3031,2924$, $1635,1507,1455,1228,1168,1012,758,699 \mathrm{~cm}^{-1} ;{ }^{1} \mathrm{H}$ and ${ }^{13} \mathrm{C}$ NMR $\left(\mathrm{CDCl}_{3}\right)$ spectroscopic data, see Table 2; positive HRESITOFMS $m / z$ 617.2751 [M+H] $]^{+}$(calcd for $\mathrm{C}_{37} \mathrm{H}_{37} \mathrm{~N}_{4} \mathrm{O}_{5}, 617.2785$ ).

Cambodine D (5). Colourless amorphous solid, $\mathrm{mp}$ 205$207{ }^{\circ} \mathrm{C} ;[\alpha]_{\mathrm{D}}^{34}-131(\mathrm{c} 0.2, \mathrm{MeOH}) ; \operatorname{ECD}(\mathrm{MeOH})(\Delta \varepsilon) 286(+3.98)$, 244 (-46.45), 224 (-8.47) nm; IR (KBr) $\nu_{\max } 3289,3036,1682$, 1670, 1656, 1624, 1507, 1291, 1228, 1158, 1000, 752, $699 \mathrm{~cm}^{-1}$; ${ }^{1} \mathrm{H}$ and ${ }^{13} \mathrm{C} \mathrm{NMR}\left(\mathrm{CDCl}_{3}\right)$ spectroscopic data, see Table 2; positive HRESITOFMS $\mathrm{m} / \mathrm{z}$ 555.2929 $[\mathrm{M}+\mathrm{H}]^{+}$(calcd for $\left.\mathrm{C}_{31} \mathrm{H}_{41} \mathrm{~N}_{4} \mathrm{O}_{4}, 555.2941\right)$.

Cambodine E (6). Colourless needles, mp 135-137 ${ }^{\circ} \mathrm{C}$; $[\alpha]_{\mathrm{D}}^{38}-169$ (c 0.2, MeOH); ECD (MeOH) $(\Delta \varepsilon) 286(+4.25), 243$ (-88.99), 220 (-14.47) nm; IR (film) $\nu_{\max } 3289,1682,1670,1624$, 1507, 1228, 752, $699 \mathrm{~cm}^{-1} ;{ }^{1} \mathrm{H}$ and ${ }^{13} \mathrm{C}$ NMR $\left(\mathrm{CDCl}_{3}\right)$ spectroscopic data, see Table 2; EIMS m/z 623 (1), 599 (1), 510 (38), 509 (100), 227 (12); positive HRESITOFMS $m / z 623.2606[\mathrm{M}+\mathrm{Na}]^{+}$ (calcd for $\mathrm{C}_{37} \mathrm{H}_{36} \mathrm{~N}_{4} \mathrm{O}_{4} \mathrm{Na}, 623.2628$ ). 
Frangufoline (7). Colourless needles, mp 216-218 ${ }^{\circ} \mathrm{C}$, lit: ${ }^{43}$ 246-248 ${ }^{\circ} \mathrm{C} ;[\alpha]_{\mathrm{D}}^{28}-219$ (c $0.2, \mathrm{CHCl}_{3}$ ), lit: ${ }^{32}[\alpha]_{\mathrm{D}}-316$ (c 1.25, $\mathrm{CHCl}_{3}$ ), lit: ${ }^{9}[\alpha]_{\mathrm{D}}-299\left(\mathrm{c} 0.1, \mathrm{CHCl}_{3}\right) ; \mathrm{ECD}(\mathrm{MeOH})(\Delta \varepsilon) 284$ (+2.26), 237 (-21.24), $215(-8.18) \mathrm{nm} ;{ }^{1} \mathrm{H}$ and ${ }^{13} \mathrm{C}$ NMR $(300 / 75$ $\mathrm{MHz}, \mathrm{CDCl}_{3}$, see ESI $\dagger$ ); negative ESIMS $m / z 533[\mathrm{M}-\mathrm{H}]^{-}(100)$, positive ESIMS $m / z 535[\mathrm{M}+\mathrm{H}]^{+}(100)$.

Lotusanine B (8). Colourless amorphous solid, mp 185$187{ }^{\circ} \mathrm{C} ;[\alpha]_{\mathrm{D}}^{34}-118(\mathrm{c} 0.2, \mathrm{MeOH})$, lit: ${ }^{20}[\alpha]_{\mathrm{D}}$ racemate; ECD $(\mathrm{MeOH})(\Delta \varepsilon) 283(+1.80), 237(-10.92), 220(-5.92) \mathrm{nm} ;{ }^{1} \mathrm{H}$ and ${ }^{13} \mathrm{C} \mathrm{NMR}\left(300 / 75 \mathrm{MHz} \mathrm{CDCl}_{3}\right.$, see ESI $\left.\dagger\right)$; negative ESIMS $m / z 619$ $[\mathrm{M}-\mathrm{H}]^{-}(100)$.

Crystal data of 6. $\mathrm{C}_{37} \mathrm{H}_{36} \mathrm{~N}_{4} \mathrm{O}_{4} \cdot \mathrm{H}_{2} \mathrm{O}, M_{\mathrm{W}}=618.74$, orthorhombic, dimensions: $0.20 \times 0.15 \times 0.10 \mathrm{~mm}, D=$ $1.273 \mathrm{~g} \mathrm{~cm}^{-3}$, space group $P 2{ }_{1} 2_{1} 2_{1}, Z=4, a=8.3830(1), b=$ 9.5920(1), $c=16938 / 7921$, number of observations $[I>2 \sigma(I)]$ 7250 , final $R$ indices $[I>2 \sigma(I)]: R_{1}=0.0427, \mathrm{w} R_{2}=0.0893$. The structure was solved by the direct method using SIR97 ${ }^{51}$ and refined with a full-matrix least-squares calculation on $F^{2}$ using SHELXL-97. ${ }^{52}$ Crystallographic data have been deposited at the Cambridge Crystallographic Data Centre under the reference number CCDC 1469415.

\section{Calculation of ECD spectra}

Conformational analysis of all structures were carried out, the ground state geometries were computed at the M062X/6-311G level of theory. Excited states were performed by TD-DFT using M062X/6-311G(d,p) method. Geometry optimization and TD-DFT computations were both carried out with CPCM solvation model in $\mathrm{MeOH}$ solution. All quantum chemical calculations were performed with Gaussian 09 programs. ${ }^{53}$ The ECD spectra were simulated with overlapping Gaussian functions with sigma $(\sigma)=0.25 \mathrm{eV}$ fitting parameter using Gauss Sum program. ${ }^{54}$ Analysis of the excited states was carried out with Gauss Sum program.

\section{Bioassay procedure}

The antimalarial activity was assayed against the parasite Plasmodium falciparum (K1, multidrug resistant strain), which was cultured continuously using the method of Trager and Jensen. ${ }^{45}$ An in vitro quantitative assessment of the antiplasmodial activity was performed by means of the microculture radioisotope technique based upon the method described by Desjardins. $^{46}$ The inhibitory concentration that causes a $50 \%$ reduction in parasite growth was indicated by the in vitro uptake of $3[\mathrm{H}]$-hypoxanthine by $P$. falciparum. Under the same test system, the standard compound, dihydroartemisinin, showed an $\mathrm{IC}_{50}$ value of $4.29 \mathrm{nM}$. By employing the microplate Alamar blue assay described by Collins and Franzblau, ${ }^{47}$ the antimycobacterial activity was evaluated against Mycobacterium tuberculosis $\mathrm{H}_{37} \mathrm{Ra}$ (purchased from ATCC). The standard drugs for the antimycobacterial assay, isoniazid and kanamycin sulfate, showed MICs of 0.44 and $4.29 \mu \mathrm{M}$, respectively. By using the previously described colorimetric method, ${ }^{48}$ the cytotoxicity of the sample was determined. The reference substance, ellipticine, exhibited cytotoxic activity against human epidermod carcinoma (KB, ATCC CCL-87), human breast cancer (BC-1,
ATCC11778), and human small cell lung cancer (NCI-H187, ATCC CRL-5804) cells, with $\mathrm{IC}_{50}$ values of 5.39, 5.92, and 1.58 $\mu \mathrm{M}$, respectively. The cytotoxicity against an African green monkey kidney (Vero) cell line was evaluated by green fluorescent protein (GFP) detection, and ellipticine was used as a positive control. ${ }^{55}$

\section{Conclusions}

The present study revealed that the root bark of $Z$. cambodiana is a rich source of 14-membered ring cyclopeptide alkaloids. Six new 14-membered cyclopeptide alkaloids, cambodines A-F (16) along with two known cyclopeptides, frangufoline and lotosanine B were obtained. Compounds 1 and 3 are rare 5(14)-type alkaloids possessing an imidazolidin-4-one ring in the terminal unit. Interestingly, the in vitro antimalarial assay disclosed that only the cyclopeptide with the 5-(sec-butyl)-1,2dimethylimidazolidin-4-one exhibited significant activity. Some of the isolated alkaloids displayed antimycobacterial and cytotoxic properties, and most of them were nontoxic to Vero cells. Other bioactivity evaluations of these Ziziphus constituents are under active investigation.

\section{Conflicts of interest}

There are no conflicts of interest to declare.

\section{Acknowledgements}

This work was supported by The Royal Golden Jubilee PhD (RGJ) Program (PHD/0326/2552), The Thailand Research Fund and the Center of Excellence for Innovation in Chemistry (PERCHCIC), Office of the Higher Education Commission. Partial support from the Faculty of Science, Srinakharinwirot University is gratefully acknowledged. P. K. thanks Mahidol University for financial support. We are indebted to the Bioassay Research Facility of BIOTEC for the bioactivity assays and to the Department of Chemistry, Ramkhamhaeng University for the measurements of the ESIMS and HRESIMS spectra. The authors would like to acknowledge National e-Science Infrastructure Consortium for providing computing resources that have partly contributed to the research results reported within this paper.

\section{References}

1 B. Bhattachachryya and B. M. Johri, Flowering Plants, Taxonomy and Phylogeny, Narosa Publishing House, New Delhi, 1998, pp. 326-328.

2 T. Smitinand, Thai plant names (Revised edition), The Forest Herbarium, Bangkok, 2014, pp. 564-565.

3 K. B. Kang, H. W. Kim, J. W. Kim, W. K. Oh, J. Kim and S. H. Sung, J. Nat. Prod., 2017, 80, 1048-1054.

4 S. R. Wang and W. S. Fang, Curr. Top. Med. Chem., 2009, 9, 1581-1596.

5 Q.-H. Gao, C.-S. Wu and M. Wang, J. Agric. Food Chem., 2013, 61, 3351-3363. 
6 B. Yang, H. Yang, F. Chen, Y. Huad and Y. Jiang, Analyst, 2013, 138, 6881-6888.

7 E. Tuenter, V. Exarchou, S. Apers and L. Pieters, Phytochem. Rev., 2017, 16, 623-637.

8 H. R. El-Seedi, M. H. Zahra, U. Goransson and R. Verpoorte, Phytochem. Rev., 2007, 6, 143-165.

9 N.-H. Tan and J. Zhou, Chem. Rev., 2006, 106, 840-895.

10 M. A. Beg, U. V. S. Teotia and S. Farooq, J. Med. Plants Stud., 16, 4, 230-233.

11 M. Goyal, B. P. Nagori and D. Sasmal, Spatula DD, 2012, 2, 107-116.

12 S. Suksamrarn, P. Panseeta, S. Kunchanawatta, T. Distaporn, S. Ruktasing and A. Suksamrarn, Chem. Pharm. Bull., 2006, 54, 535-537.

13 P. Panseeta, K. Lomchoey, S. Prabpai, P. Kongsaeree, A. Suksamrarn, S. Ruchirawat and S. Suksamrarn, Phytochemistry, 2011, 72, 909-915.

14 S. Suksamrarn, N. Suwannapoch, N. Aunchai, M. Kuno, P. Ratananukul, R. Haritakun, C. Jansakul and S. Ruchirawat, Tetrahedron, 2005, 61, 1175-1180.

15 K. Tangjitman, C. Wongsawad, K. Kamwong, T. Sukkho and C. Trisonthi, J. Ethnobiol. Ethnomed., 2015, 11, 1-13.

16 S. Hout, A. Chea, S.-S. Bun, R. Elias, M. Gasquet, P. TimonDavid, G. Balansard and N. Azas, J. Ethnopharmacol., 2006, 107, 12-18.

17 X. Li, T. Ohtsuki, S. Shindo, S. Sato, T. Koyano, S. Preeprame, T. Kowithayakorn and M. Ishibashi, Planta Med., 2007, 73, 1195-1196.

18 M. A. Arai, C. Tateno, T. Hosoya, T. Koyano, T. Kowithayakorn and M. Ishibashi, Bioorg. Med.Chem., 2008, 16, 9420-9424.

19 B. H. Han, M. H. Park and Y. N. Han, Phytochemistry, 1990, 29, 3315-3319.

20 M. Abu-Zarga, S. Sabri and A. Al-Aboudi, J. Nat. Prod., 1995, 58, 504-511.

21 S. D. Zhao, L. Shen, D. Q. Luo and H. J. Zhu, Curr. Org. Chem., 2011, 15, 1843-1862.

22 X.-C. Li, D. Ferreira and Y. Ding, Curr. Org. Chem., 2010, 14, 1678-1697.

23 C. Diedrich and S. Grimme, J. Phys. Chem. A, 2003, 107, 2524-2539.

24 P. J. Stephens, D. M. McCann, F. J. Devlin, J. R. Cheeseman and M. J. Frisch, J. Am. Chem. Soc., 2004, 126, 7514-7521.

25 D. M. McCann and P. J. Stephens, J. Org. Chem., 2006, 71, 6074-6098.

26 G. Bringmann, T. Bruhn, K. Maksimenka and Y. Hemberger, Eur. J. Org. Chem., 2009, 2009, 2717-2727.

27 J. Frelek, A. Fryszkowska, M. Kwit and R. Ostaszewski, Tetrahedron: Asymmetry, 2006, 17, 2469-2478.

28 B.-D. Zhou, J. Ren, X.-C. Liu and H.-J. Zhu, Tetrahedron, 2013, 69, 1189-1194.

29 A. E. Nugroho and H. Morita, J. Nat. Med., 2014, 68, 1-10.

30 C.-Y. Mang, C.-P. Liu, G.-M. Liu, B. Jiang, H. Lan, K.-C. Wub, Y. Yan, H.-F. Li, M.-H. Yang and Y. Zhao, Spectrochim. Acta A., 2015, 136, 1401-1408.

31 B. Komjáti, Á. Urai, S. Hosztafi, J. Kökösi, B. Kováts, J. Nagy and P. Horváth, Spectrochim. Acta A., 2016, 155, 95-102.
32 D. C. Gournelis, G. G. Laskaris and R. Verpoorte, in Progress in the Chemistry of Organic Natural Products, ed. W. Herz, H. Falk, G. W. Kirby, R. E. Moore and C. H. Tamm, SpringerVerlag/Wein, New York, 1998, 75, pp. 1-179.

33 R. Tschesche, M. Elgamal and G. Eckhardt, Chem. Ber., 1977, 110, 2649-2655.

34 A. H. Shah, V. B. Pandey, G. Eckhard and R. Tschesche, Phytochemistry, 1985, 24, 2765-2767.

35 H. Lin, C.-H. Chen, B.-J. You, K. C. S. Chen Liu and S.-S. Lee, J. Nat. Prod., 2000, 63, 1338-1343.

36 A. F. Morel, G. Maldaner, V. Ilha, F. Missau, U. F. Silva and I. I. Dalcol, Phytochemistry, 2005, 66, 2571-2576.

37 G. Maldaner, P. Marangon, V. Ilha, M. S. B. Caro, R. A. Burrow, I. I. Dalcol and A. F. Morel, Phytochemistry, 2011, 72, 804-809.

38 J. Han, C.-J. Ji, W.-J. He, Y. Shen, Y. Leng, W.-Y. Xu, J.-T. Fan, G.-Z. Zeng, L.-D. Kong and N.-H. Tan, J. Nat. Prod., 2011, 74, 2571-2575.

39 M. A. Mostardeiro, V. Ilha, J. Dahmer, M. S. B. Caro, I. I. Dalcol, U. F. da Silva and A. F. Morel, J. Nat. Prod., 2013, 76, 1343-1350.

40 R. Tschesche, J. Rheingans and H.-W. Fehhaber, Chem. Ber., 1967, 100, 3924-3936.

41 R. Tschesche, H. Last and H.-W. Fehhaber, Chem. Ber., 1967, 100, 3937-3943.

42 B. H. Han, M. H. Park and Y. N. Han, Pure Appl. Chem., 1989, 61, 443-448.

43 D. Xiao, S. P. East and M. M. Joullie, Tetrahedron Lett., 1998, 39, 9631-9632.

44 P. L. de Oliveira, C. M. A. Tanaka, L. Kato, C. C. da Silva, R. P. Medina, A. P. Moraes, J. R. Sabino and C. M. A. de Oliveira, J. Nat. Prod., 2009, 72, 1195-1197.

45 W. Trager and J. B. Jensen, Science, 1976, 193, 673-675.

46 R. E. Desjardins, C. J. Canfield, J. D. Haynes and J. D. Chulay, Antimicrob. Agents Chemother., 1979, 17, 710-718.

47 L. Collins and S. G. Franzblau, Antimicrob. Agents Chemother., 1997, 41, 1004-1009.

48 P. Skehan, R. Storeng, D. Scudiero, A. Monks, J. McMahon, D. Vistica, J. T. Warren, H. Bokesch, S. Kenny and M. R. Boyd, J. Natl. Cancer Inst., 1990, 82, 1107-1112.

49 E. Tuenter, V. Exarchou, A. Baldé, P. Cos, L. Maes, S. Apers and L. Pieters, J. Nat. Prod., 2016, 79, 1746-1751.

50 M. Toumi, V. Rincheval, A. Young, D. Gergeres, E. Turos, F. Couty, B. Mignotte and G. Evano, Eur. J. Org. Chem., 2009, 3368-3386.

51 A. Altomare, M. C. Burla, M. Camalli, G. L. Cascarano, C. Giacovazzo, A. Guagliardi, A. G. G. Moliterni, G. Polidori and R. Spagna, J. Appl. Cryst., 1999, 32, 115-119.

52 G. M. Sheldrick, Acta Cryst., 2008, A64, 112-122.

53 M. J. Frisch, G. W. Trucks, H. B. Schlegel, G. E. Scuseria, M. A. Robb, J. R. Cheeseman, G. Scalmani, V. Barone, B. Mennucci, G. A. Petersson, H. Nakatsuji, M. Caricato, X. Li, H. P. Hratchian, A. F. Izmaylov, J. Bloino, G. Zheng, J. L. Sonnenberg, M. Hada, M. Ehara, K. Toyota, R. Fukuda, J. Hasegawa, M. Ishida, T. Nakajima, Y. Honda, O. Kitao, H. Nakai, T. Vreven, J. A. Montgomery Jr., J. E. Peralta, F. Ogliaro, M. J. Bearpark, J. Heyd, 
E. N. Brothers, K. N. Kudin, V. N. Staroverov, R. Kobayashi, J. Normand, K. Raghavachari, A. P. Rendell, J. C. Burant, S. S. Iyengar, J. Tomasi, M. Cossi, N. Rega, N. J. Millam, M. Klene, J. E. Knox, J. B. Cross, V. Bakken, C. Adamo, J. Jaramillo, R. Gomperts, R. E. Stratmann, O. Yazyev, A. J. Austin, R. Cammi, C. Pomelli, J. W. Ochterski, R. L. Martin, K. Morokuma, V. G. Zakrzewski, G. A. Voth, P. Salvador, J. J. Dannenberg, S. Dapprich, A. D. Daniels,
Ö. Farkas, J. B. Foresman, J. V. Ortiz, J. Cioslowski and D. J. Fox, Gaussian 09 Rev B01, Gaussian, Inc., Wallingford, CT, USA, 2009.

54 N. M. O'Boyle, A. L. Tenderholt and K. M. Langner, J. Comput. Chem., 2008, 29, 839-845.

55 L. Hunt, M. Jordan, M. De Jesus and F. M. Wurm, Biotechnol. Bioeng., 1999, 65, 201-205. 